Article

\title{
Synthesis, Characterization, and Biologic Activity of New Acyl Hydrazides and 1,3,4-Oxadiazole Derivatives
}

\author{
Irina Zarafu ${ }^{1, *, \dagger}$, Lilia Matei ${ }^{2,3, \dagger}$, Coralia Bleotu ${ }^{2,3, \dagger}{ }^{+}$Petre Ionita ${ }^{1}{ }^{(\mathbb{C}}$, Arnaud Tatibouët ${ }^{4}$, \\ Anca Păun ${ }^{1}$, Ioana Nicolau ${ }^{1}$, Anamaria Hanganu ${ }^{3,5}{ }^{\circ}$, Carmen Limban ${ }^{6}$, Diana Camelia Nuta ${ }^{6}$, \\ Roxana Maria Nemes ${ }^{7}$, Carmen Cristina Diaconu ${ }^{2,+}$ and Cristiana Radulescu ${ }^{8,9, *(\text { ) }}$ \\ 1 Faculty of Chemistry, University of Bucharest, 050663 Bucharest, Romania; \\ petre.ionita@chimie.unibuc.ro (P.I.); anca.paun@chimie.unibuc.ro (A.P.); \\ ioana.nicolau@chimie.unibuc.ro (I.N.) \\ 2 "Stefan S Nicolau" Institute of Virology, Romanian Academy, 030304 Bucharest, Romania; \\ lilia.matei@virology.ro (L.M.); coralia.bleotu@virology.ro (C.B.); carmen.diaconu@virology.ro (C.C.D.) \\ 3 Research Institute of the University of Bucharest (ICUB), Life, Environmental and Earth Sciences Division, \\ University of Bucharest, 060023 Bucharest, Romania; anamaria.hanganu@unibuc.ro \\ 4 Institute of Organic and Analytical Chemistry ICOA-UMR7311, University of Orleans, \\ 45067 Orleans, France; arnaud.tatibouet@univ-orleans.fr \\ 5 Institute of Organic Chemistry "C.D. Nenitescu" of the Romanian Academy, 060023 Bucharest, Romania \\ 6 Faculty of Medicine, "Carol Davila” University of Medicine and Pharmacy, 020021 Bucharest, Romania; \\ carmen.limban@umfcd.ro (C.L.); diana.nuta@umfcd.ro (D.C.N.) \\ 7 National Institute of Pneumology Marius Nasta, 050152 Bucharest, Romania; roxanamarianemes@gmail.com \\ 8 Faculty of Sciences and Arts, "Valahia” University of Targoviste, 130004 Targoviste, Romania \\ 9 Institute of Multidisciplinary Research for Science and Technology, Valahia University of Targoviste, \\ 13004 Targoviste, Romania \\ * Correspondence: irina.zarafu@chimie.unibuc.ro (I.Z.); cristiana.radulescu@valahia.ro (C.R.) \\ + These authors contributed equally to this work.
}

Received: 19 June 2020; Accepted: 21 July 2020; Published: 21 July 2020

\begin{abstract}
Starting from isoniazid and carboxylic acids as precursors, thirteen new hydrazides and 1,3,4-oxadiazoles of 2-(4-substituted-phenoxymethyl)-benzoic acids were synthesized and characterized by appropriate means. Their biological properties were evaluated in terms of apoptosis, cell cycle blocking, and drug metabolism gene expression on HCT-8 and HT-29 cell lines. In vitro antimicrobial tests were performed by the microplate Alamar Blue assay for the anti-mycobacterial activities and an adapted agar disk diffusion technique for other non-tubercular bacterial strains. The best antibacterial activity (anti-Mycobacterium tuberculosis effects) was proved by 9 . Compounds 7, 8, and 9 determined blocking of G1 phase. Compound 7 proved to be toxic, inducing apoptosis in $54 \%$ of cells after $72 \mathrm{~h}$, an effect that can be predicted by the increased expression of mRNA caspases 3 and 7 after $24 \mathrm{~h}$. The influence of compounds on gene expression of enzymes implicated in drug metabolism indicates that synthesized compounds could be metabolized via other pathways than NAT2, spanning adverse effects of isoniazid. Compound 9 had the best antibacterial activity, being used as a disinfectant agent. Compounds 7, 8, and 9, seemed to have antitumor potential. Further studies on the action mechanism of these compounds on the cell cycle may bring new information regarding their biological activity.
\end{abstract}

Keywords: isoniazid; oxadiazole; synthesis; antibacterial activity; apoptosis; cell cycle; drug metabolism genes expression 


\section{Introduction}

Hydrazides represent a class of organic compounds containing a nitrogen-nitrogen covalent bond with at least one acyl substituent [1]. They are used as starting materials for the synthesis of surfactants and of various heterocycles as of 1,2,4-triazoles [2], 1,3,4-thiadiazoles [3], or 1,3,4-oxadiazoles [3,4] with pharmacological activity [5]. Hydrazides are well known for their antitumor [6], anti-inflammatory [7], analgesic [8], antibacterial [7,9], and antiviral [10] activities, while 1,3,4-oxadiazoles are known for antibacterial, antifungal, and anti-inflammatory activities [11,12].

Is well known that isoniazid (INH) is used as valuable drug for anti-tuberculosis treatments mostly against the active metabolize and multiply of Mycobacterium tuberculosis bacteria [13,14], but less effective than dormant ones [15]. The hydrazide of isonicotinic acid is considered a prodrug capable of crossing the M. tuberculosis cell wall through passive diffusion [16]. After reaching the inside of the cell [17], KatG (mycobacterial catalase-oxidase) is activating it. The active forms of INH shown different effects on the cell wall mycolic acids synthesis [18], on nucleic acids replication/transcription [19], and on bacterial respiratory metabolism, as well [20]. All this time, it never been completely discovered the complex mechanism of action of isoniazid as prodrug [21,22].

In terms of toxicity effect over the human body, the INH behavior is different for each patient. The isoniazid is degradaded mainly by acetylation with $\mathrm{N}$-acetyltransferase (NAT), which conduct to N1-acetyl-N2-isonicotinylhydrazine (acetylisoniazid) metabolite, and further, by metabolization process, result the mono-acetylhydrazine and the nontoxic di-acetylhydrazine [23-25]. The polymorphisms of genes that codify NATs, also influence the metabolism of INH. On the other hand, different degrees of activity for NATs and an individual acetylation profile are determined by the presence of various polymorphisms [26]. On this basis, the humans may be classified in three classes such as slow, intermediate, and fast acetylators [27]. Therefore, a fast acetylation of INH lead to a lowering concentration of active drug [14], being responsible for applied therapy effectiveness, mostly to some patients which required single weekly doses [28]. On the other hand, for slow acetylators the risk for hepatotoxic effects occurrence is possible due to high concentrations of isoniazid metabolites [24,29,30]. Literature [22,31,32] revealed that the any change added to isoniazid molecule such as the inclusion of a functional group to the hydrazine structure could block the acetylation of the drug by NATs, therefore influencing its activity and toxicity.

It had been previously shown that isoniazid derivatives exhibited a good anti-mycobacterial activity, some of them being more active than isoniazid or other anti-tubercular drugs used in the current therapy regimens [33-38]. Various studies have postulated that the majority of isoniazid derivatives are activated before reaching the intracellular medium of $M$. tuberculosis [39]. On the other hand, based on QSAR study [40], the Ventura group presumed that isoniazid derivatives activation involve the formation of electrophilic intermediate species (hydrazyl radical or ion) that are transformed in acyl radicals which can couple with $\mathrm{NADH} / \mathrm{NAD}^{+}$, the formed adducts inhibiting enoyl-acyl carrier protein reductase (InhA) activity [41].

To the best of our knowledge, the synthesis of new isoniazid derivatives based clinical drugs is important for the therapeutic field. These observations encouraged the authors to continue the previous research (i.e., synthesis, characterization, and pharmacological evaluation of new heterocyclic compounds), where hydrazides/indazoles/oxadiazoles linked with other heterocycles proved as effective antimicrobial agents [42-48]. The purpose of current study was to characterize the new synthesized isoniazid derivatives and to preliminary evaluate their biological activity to identify their usefulness as drugs in medical field.

\section{Results and Discussion}

\subsection{Synthesis and Structural Characterization}

The benzoic acid hydrazides were prepared following the method described in the general experimental procedure. The carboxylic acids were obtained by a method reported earlier by Limban 
group [49], by refluxing the phthalide with potassium p-substituted phenolates in xylene. The obtained corresponding acid was treated with thionyl chloride in 1,2-dichloroethane under reflux. The crude acid chloride thus obtained was added to isoniazid dissolved in dichloromethane and the reaction mixture was stirred at room temperature. Product formation was monitored by thin-layer chromatography on silica gel, and the obtained products were separated and purified on chromatographic columns. In the case of 2-(4-methyl/methoxy/ethyl-phenoxymethyl)-benzoic acid derivatives, the presence of two new compounds in each reaction was observed.

The newly synthesized $N, N^{\prime}$-diacylhydrazines (1-6) were diluted in toluene and treated with phosphoryl chloride. The reaction mixture was refluxed for $6 \mathrm{~h}$ and then stirred overnight at room temperature. Product formation was monitored by thin layer chromatography on silica gel. Toluene and residual phosphoryl chloride were removed under reduced pressure and the reaction products were taken up in dichloromethane and washed with $5 \% \mathrm{NaOH}$ solution and with saturated aqueous $\mathrm{NaCl}$ solution. The organic layer was dried over anhydrous sodium sulfate and the solvent distilled under reduced pressure. The newly synthesized 1,3,4-oxadiazoles were recrystallized using ethanol.

The synthesis reactions of new compounds are presented in Figure 1.

\begin{tabular}{cccc}
\hline Compound & $\mathbf{R}$ & Compound & $\mathbf{R}$ \\
\hline $\mathbf{1}$ & $\mathrm{H}$ & $\mathbf{7}$ & $\mathrm{CH}_{3}$ \\
$\mathbf{2}$ & $\mathrm{F}$ & $\mathbf{8}$ & $\mathrm{OCH}_{3}$ \\
$\mathbf{3}$ & $\mathrm{Cl}$ & $\mathbf{9}$ & $\mathrm{C}_{2} \mathrm{H}_{5}$ \\
$\mathbf{4}$ & $\mathrm{CH}_{3}$ & $\mathbf{1 0}$ & $\mathrm{H}$ \\
$\mathbf{5}$ & $\mathrm{OCH}_{3}$ & $\mathbf{1 1}$ & $\mathrm{F}$ \\
$\mathbf{6}$ & $\mathrm{C}_{2} \mathrm{H}_{5}$ & $\mathbf{1 2}$ & $\mathrm{Cl}$ \\
& & $\mathbf{1 3}$ & $\mathrm{CH}_{3}$ \\
\hline
\end{tabular}

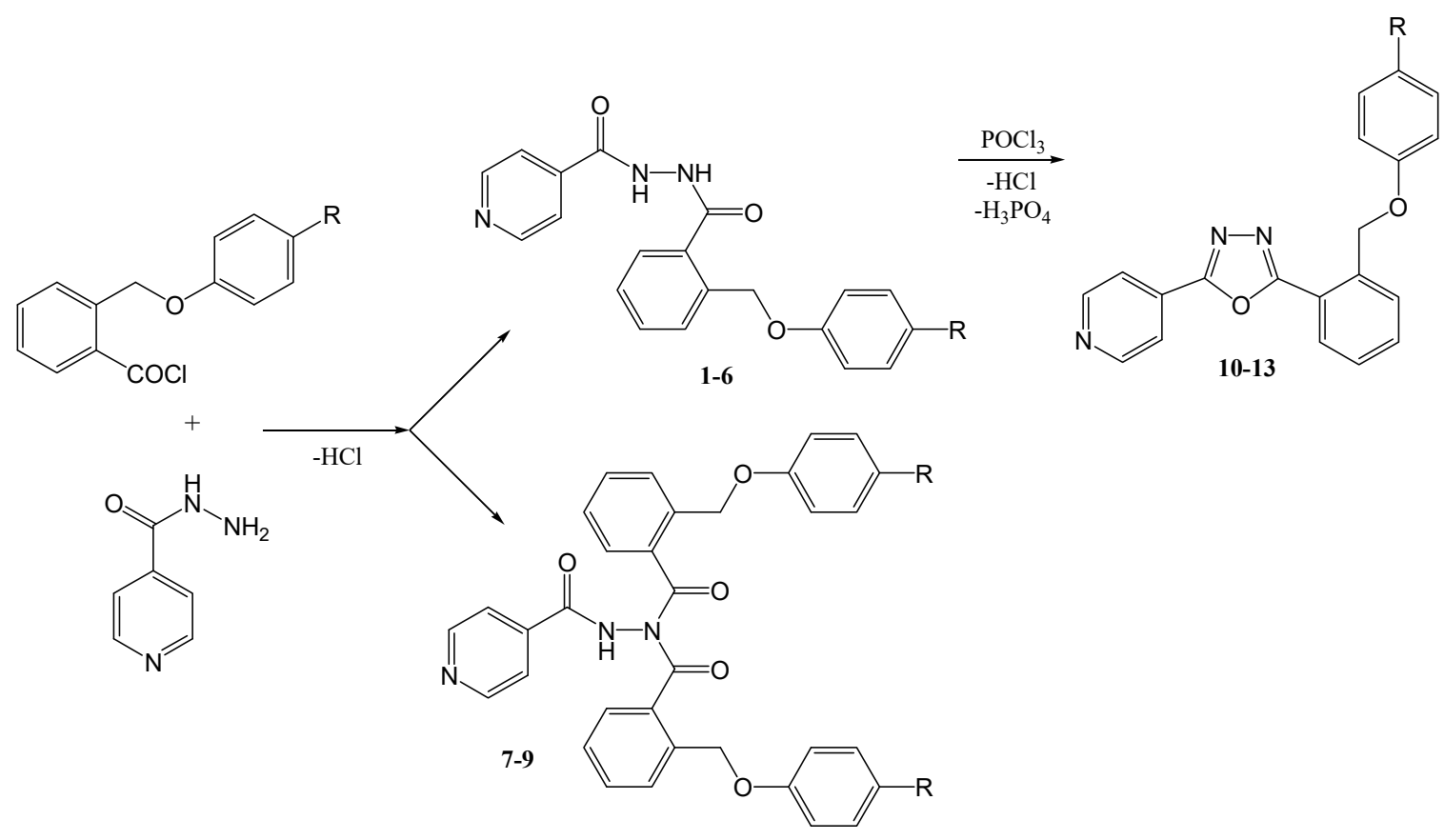

Figure 1. Synthesis of the new isoniazid derivatives.

The synthesis yields (attempts to optimize were not made), the melting points, and the $R_{f}$ values of the new compounds obtained are presented in Table 1. 
Table 1. Results obtained in the synthesis of the compounds.

\begin{tabular}{cccc}
\hline Compound & Yield [\%] & m.p. $\left[{ }^{\circ} \mathbf{C}\right]$ & $\boldsymbol{R}_{f}{ }^{\mathrm{a}, \mathrm{b}, \mathrm{c}}$ \\
\hline INH & - & $171-173$ & $0.03^{\mathrm{a}}$ \\
$\mathbf{1}$ & 52 & $128-129$ & $0.50^{\mathrm{b}}$ \\
$\mathbf{2}$ & 40 & $168-169$ & $0.57^{\mathrm{b}}$ \\
$\mathbf{3}$ & 25 & $145-146$ & $0.56^{\mathrm{b}}$ \\
$\mathbf{4}$ & 58 & $173-175$ & $0.17^{\mathrm{a}}$ \\
$\mathbf{5}$ & 54 & $108-111$ & $0.13^{\mathrm{a}}$ \\
$\mathbf{6}$ & 33 & $133-135$ & $0.17^{\mathrm{a}}$ \\
$\mathbf{7}$ & 5 & Semisolid & $0.60^{\mathrm{a}}$ \\
$\mathbf{8}$ & 2 & Semisolid & $0.52^{\mathrm{a}}$ \\
$\mathbf{9}$ & 6 & Semisolid & $0.63^{\mathrm{a}}$ \\
$\mathbf{1 0}$ & 62 & $210-211$ & $0.72^{\mathrm{b}}$ \\
$\mathbf{1 1}$ & 65 & $298-299$ & $0.79^{\mathrm{b}}$ \\
$\mathbf{1 2}$ & 68 & $341-342$ & $0.75^{\mathrm{b}}$ \\
$\mathbf{1 3}$ & 73 & $249-250$ & $0.60^{\mathrm{c}}$ \\
\hline AcOEt: $\mathrm{CH}_{2} \mathrm{Cl}_{2}=1: 1,{ }^{\mathrm{b}} \mathrm{AcOEt}: \mathrm{MeOH}=9: 1,{ }^{\mathrm{c}} \mathrm{CH}_{2} \mathrm{Cl}_{2}: \mathrm{MeOH}=5: 1$.
\end{tabular}

The chemical structure of the newly synthesized compounds was confirmed by ${ }^{1} \mathrm{H}-\mathrm{NMR}$, ${ }^{13} \mathrm{C}-\mathrm{NMR}$, IR, and by elemental analysis. The ${ }^{1} \mathrm{H}-\mathrm{NMR}$ spectra of compounds 1-6 showed two singlets at 10.11-11.20 ppm and 9.72-10.55 ppm, which represent the two hydrazide protons (NH-NH, deuterable), while the ${ }^{1} \mathrm{H}-\mathrm{NMR}$ spectra of compounds 7-9 showed only one singlet at 8.53-11.97 ppm, corresponding to the NH-N proton. This indicates that compounds 1-6 are $N, N^{\prime}$-disubstituted, while compounds 7-9 are $N, N, N^{\prime}$-trisubstituted.

FTIR spectra showed the $C=O$ peak at $1690-1669 \mathrm{~cm}^{-1}$ and the $C-N$ peak at $1609-1592 \mathrm{~cm}^{-1}$, and, also, in the case of compounds $\mathbf{1 - 9}$, the $\mathrm{N}-\mathrm{H}$ stretching vibration at $3271-3191 \mathrm{~cm}^{-1}$. The stretching vibrations of the aromatic rings $(C=C-C)$ are situated at $1608-1443 \mathrm{~cm}^{-1}$. For all compounds it can distinguish the 1,2- and 1,4-disubstitution at 748-735 $\mathrm{cm}^{-1}$ and $841-811 \mathrm{~cm}^{-1}$, respectively. The complete interpretation of ${ }^{1} \mathrm{H}-,{ }^{13} \mathrm{C}-\mathrm{NMR}$ and IR spectra and the elemental analyses of new compounds are presented in the experimental part.

All compounds were subjected to MS analysis, the signals of molecular ions $[\mathrm{M}+\mathrm{H}]$ corresponding to the calculated molecular weight and structure of these compounds.

\subsection{Biological Evaluation}

\subsubsection{Antimicrobial Activity}

Taking into account that isoniazid derivatives are known for their anti-tubercular activity $[30,32,36]$, the newly synthesized derivatives of isoniazid were tested for their in vitro activity against a clinical strain of $M$. tuberculosis. The tested compounds were quantitatively assayed using serial binary dilutions ranging from $25 \mu \mathrm{g} / \mathrm{mL}$ to $0.012 \mu \mathrm{g} / \mathrm{mL}$. None of the new synthesized compounds proved to have anti-tubercular activity, apart from compound 9 that inhibited the growth of $M$. tuberculosis at a concentration of $6.25 \mu \mathrm{g} / \mathrm{mL}$ (Table 2). 
Table 2. The anti-tubercular evaluation of the new compounds.

\begin{tabular}{cc}
\hline Compound & MIC $^{\mathbf{a}}[\mu \mathrm{g} / \mathrm{mL}]$ \\
\hline INH & 0.098 \\
$\mathbf{1}$ & $>25$ \\
$\mathbf{2}$ & $>25$ \\
$\mathbf{3}$ & $>25$ \\
$\mathbf{4}$ & $>25$ \\
$\mathbf{5}$ & $>25$ \\
$\mathbf{6}$ & 25 \\
$\mathbf{7}$ & 25 \\
$\mathbf{8}$ & 25 \\
$\mathbf{9}$ & 6.25 \\
$\mathbf{1 0}$ & $>25$ \\
$\mathbf{1 1}$ & $>25$ \\
$\mathbf{1 2}$ & $>25$ \\
$\mathbf{1 3}$ & $>25$
\end{tabular}

a Anti-mycobacterial activity (minimum inhibitory concentration (MIC)) against a clinical strain of $M$. tuberculosis.

The minimal inhibitory concentration (MIC) of the compound $\mathbf{9}$ was moderate, which is in the range of those reported for other isoniazid derivatives obtained by combination with acid chlorides [33-38]. A very active derivative against $M$. tuberculosis is 1-isonicotinyl-2-nonanoyl hydrazine, superior to isoniazid with a very low minimal inhibitory concentration value of $0.025 \mu \mathrm{g} / \mathrm{mL}$ [38]. Other compounds from this class exhibited MIC values ranging between 0.39 and $71.6 \mu \mathrm{g} / \mathrm{mL}$ [33-37]. Regarding the isoniazid-derived 1,3,4-oxadiazoles reported in literature, few of them proved anti-tuberculosis activity [50].

In order to establish if these new synthesized compounds have antibacterial activity against other microbial species and to determine the spectrum of their activity, the novel derivatives were tested on other, non-tuberculosis, bacterial strains isolated from clinical specimens, both Gram-positive (e.g., Staphylococcus hominis, Staphylococcus aureus, and coagulase-negative staphylococci) and Gram-negative (e.g., Escherichia coli, Klebsiella pneumoniae, Proteus mirabilis, Citrobacter koseri, Morganella morganni, Acinetobacter baumanii, and Pseudomonas aeruginosa), using an adapted diffusion technique. The most active derivative proved to be compound $\mathbf{9}$, which inhibited the growth of the majority of tested strains, followed by the compounds $\mathbf{6}$ and 7 . The less active derivatives were compounds 1, 3, and 10-13. On the other hand, the $N, N, N^{\prime}$-triacylhydrazines 7-9 exhibited a better antibacterial activity than their corresponding $N, N^{\prime}$-diacylhydrazines 4-6, as well as the rest of tested compounds (Table 3). According to previously reported data compounds with similar structures proved inhibitory activity on the growth of Staphylococcus aureus, Enterococcus faecalis, Pseudomonas aeruginosa, and Escherichia coli [33-37]. 
Table 3. The antimicrobial evaluation of the new synthesized compounds.

\begin{tabular}{|c|c|c|c|c|c|c|c|c|c|c|c|c|c|c|}
\hline Compound & INH & 1 & 2 & 3 & 4 & 5 & 6 & 7 & 8 & 9 & 10 & 11 & 12 & 13 \\
\hline Micrococcaceae & & & & & & & & & & & & & & \\
\hline Staphylococcus hominis 1813 & - & - & - & - & - & - & - & - & - & $+/-$ & - & - & - & - \\
\hline Staphylococcus hominis $2610 / 2710$ & - & - & - & - & - & $+/-$ & $+/-$ & $+/-$ & $+/-$ & $+/-$ & - & - & - & - \\
\hline Staphylococcus aureus & - & - & - & - & - & - & - & $+/-$ & - & $+/-$ & - & - & - & - \\
\hline Staphylococcus aureus 2669 & - & - & - & - & - & - & - & $+/-$ & $+/-$ & + & - & - & - & - \\
\hline Staphylococcus aureus 2754 & - & - & - & - & - & - & $+/-$ & $+/-$ & - & + & - & - & - & - \\
\hline Staphylococcus aureus ATCC 25923 & - & - & - & - & - & - & - & - & - & + & - & - & - & - \\
\hline Staphylococcus aureus ATCC 29213 & - & - & - & - & - & $+/-$ & $+/-$ & $+/-$ & $+/-$ & $+/-$ & - & - & - & - \\
\hline Coagulase-negative Staphylococcus sp. 2672 & - & - & - & - & - & - & - & - & - & $+/-$ & - & - & - & - \\
\hline Coagulase-negative Staphylococcus sp. 3026 & - & - & $+/-$ & - & - & - & - & - & $+/-$ & $+/-$ & - & - & - & - \\
\hline Coagulase-negative Staphylococcus sp. 196 & - & - & - & - & - & - & - & $+/-$ & - & $+/-$ & - & - & - & - \\
\hline $\begin{array}{c}\text { Coagulase-negative Staphylococcus sp. } 1785 \\
\text { Streptococcaceae }\end{array}$ & - & - & - & - & - & - & - & - & - & + & - & - & - & - \\
\hline Enterococcus faecalis ATCC 29212 & - & - & - & - & - & - & - & - & - & $+/-$ & - & - & - & - \\
\hline $\begin{array}{c}\text { Enterococcus faecalis } 2920 \\
\text { Enterobacteriaceae }\end{array}$ & - & - & - & - & - & - & - & - & - & + & - & - & - & - \\
\hline Enterobacter cloacae 1845 & + & - & - & - & - & - & - & - & - & $+/-$ & - & - & - & - \\
\hline Enterobacter cloacae 3016 & - & - & - & - & - & $+/-$ & $+/-$ & $+/-$ & $+/-$ & + & - & - & - & - \\
\hline Citrobacter koseri 1742 & - & - & - & - & $+/-$ & $+/-$ & $+/-$ & $+/-$ & $+/-$ & $+/-$ & - & - & - & - \\
\hline Morganella morganni 2810 & - & - & - & - & - & - & - & - & - & - & - & - & - & - \\
\hline Escherichia coli 410 & - & - & - & - & - & $+/-$ & $+/-$ & - & - & $+/-$ & - & - & - & - \\
\hline Escherichia coli 1455 & - & - & - & - & - & $+/-$ & $+/-$ & $+/-$ & $+/-$ & + & - & - & - & - \\
\hline Escherichia coli 1461 & - & - & - & - & - & - & $+/-$ & $+/-$ & $+/-$ & + & - & - & - & - \\
\hline Escherichia coli 1777 & - & - & - & - & - & $+/-$ & $+/-$ & $+/-$ & - & $+/-$ & - & - & - & - \\
\hline Escherichia coli ATCC 25922 & - & - & - & - & - & - & - & $+/-$ & - & + & - & - & - & - \\
\hline Klebsiella pneumoniae 1756 & - & - & - & - & - & - & $+/-$ & - & - & - & - & - & - & - \\
\hline Klebsiella pneumoniae 3029 & - & - & - & - & - & $+/-$ & $+/-$ & - & - & $+/-$ & - & - & - & - \\
\hline Salmonella typhimurium ATCC 14028 & - & - & - & - & - & $+/-$ & $+/-$ & $+/-$ & $+/-$ & $+/-$ & - & - & - & - \\
\hline Serratia marcescens 1142 & - & - & - & - & $+/-$ & $+/-$ & $+/-$ & $+/-$ & $+/-$ & $+/-$ & - & - & - & - \\
\hline $\begin{array}{c}\text { Shigella sonnei ATCC } 25931 \\
\text { Pseudomonadaceae }\end{array}$ & - & - & - & - & - & - & - & - & - & - & - & - & - & - \\
\hline Pseudomonas aeruginosa ATCC 27853 & - & - & - & - & - & - & - & $+/-$ & - & $+/-$ & - & - & - & - \\
\hline Pseudomonas aeruginosa 165 & - & - & - & - & - & - & $+/-$ & $+/-$ & $+/-$ & $+/-$ & - & - & - & - \\
\hline Pseudomonas aeruginosa 1144 & - & - & - & - & - & $+/-$ & $+/-$ & $+/-$ & $+/-$ & $+/-$ & - & - & - & - \\
\hline
\end{tabular}


Table 3. Cont

\begin{tabular}{|c|c|c|c|c|c|c|c|c|c|c|c|c|c|c|}
\hline Compound & INH & 1 & 2 & 3 & 4 & 5 & 6 & 7 & 8 & 9 & 10 & 11 & 12 & 13 \\
\hline Pseudomonas aeruginosa 1150 & - & - & - & - & - & $+/-$ & $+/-$ & $+/-$ & - & $+/-$ & - & - & - & - \\
\hline $\begin{array}{l}\text { Pseudomonas putida } 160 \\
\text { Xanthomonadaceae }\end{array}$ & $+/-$ & - & - & - & - & $+/-$ & $+/-$ & $+/-$ & - & $+/-$ & - & - & - & - \\
\hline $\begin{array}{c}\text { Stenotrophomonas maltophilia } 412 \\
\text { Moraxellaceae }\end{array}$ & - & - & - & - & $+/-$ & $+/-$ & $+/-$ & $+/-$ & $+/-$ & $+/-$ & - & - & - & - \\
\hline Acinetobacter baumanii 122 & - & - & - & - & - & - & - & - & - & + & - & - & - & - \\
\hline Acinetobacter baumanii 125 & - & - & - & - & - & $+/-$ & $+/-$ & - & - & + & - & - & - & - \\
\hline Acinetobacter baumanii 247 & - & - & - & - & - & - & $+/-$ & - & - & + & - & - & - & - \\
\hline Acinetobacter baumanii 411 & - & - & - & - & - & $+/-$ & $+/-$ & $+/-$ & $+/-$ & + & - & - & - & - \\
\hline
\end{tabular}

Susceptible (+); Resistant (-); Intermediate (+/-). 
2.2.2. The Influence of the New Isoniazid Derivatives on the Expression Levels of Some Genes Implicated in Drug Metabolism

The main metabolic pathway of isoniazid and similar compounds in human body involves its $\mathrm{N}$-acetylation and the increased expression of NAT1 and NAT2 genes, which is suggested to be associated with a better rate of metabolization. In this context, the influence of newly synthesized substances on NAT1 and NAT2 expression in eukaryotic cells was evaluated in two cell lines-HCT-8 and HT-29—at a concentration of $50 \mu \mathrm{g} / \mathrm{mL}$. As we previously reported, the HT-29 cell line presents NAT2 5 genotype, while the HCT- 8 cell line presents the NAT2*6 genotype [51]. Isoniazid decreased the expression of NAT1 and NAT2 in both cell lines, as well as compounds $\mathbf{2 , 4} \mathbf{4 0}$, and 11. NAT1 and NAT2 gene expressions were increased by compounds $\mathbf{6}$ and $\mathbf{9}$ in both HT-29 and HCT-8 cell lines. Compounds 3 and $\mathbf{5}$ increased the gene expression of NAT1 in both used cell lines, compound 1 increased NAT1 expression only in HT-29, and compounds 7 and 8 increased it only in the HCT-8 cell line. Regarding NAT2 gene expression, it was increased by compounds $\mathbf{7}$ and $\mathbf{8}$ in both tested cell lines, by compounds 5 and 12 in HT-29 cell line, and by compound 3 in HCT- 8 cells. Generally, the NAT2 gene expression was more influenced by tested compounds in HCT-8 cell line, than in HT-29 cell line, with the exception of compounds 9-11 (Figure 2). Compounds 6-9 could be used to potentiate isoniazid metabolism in slow acetylators, and further studies should be done in this direction.

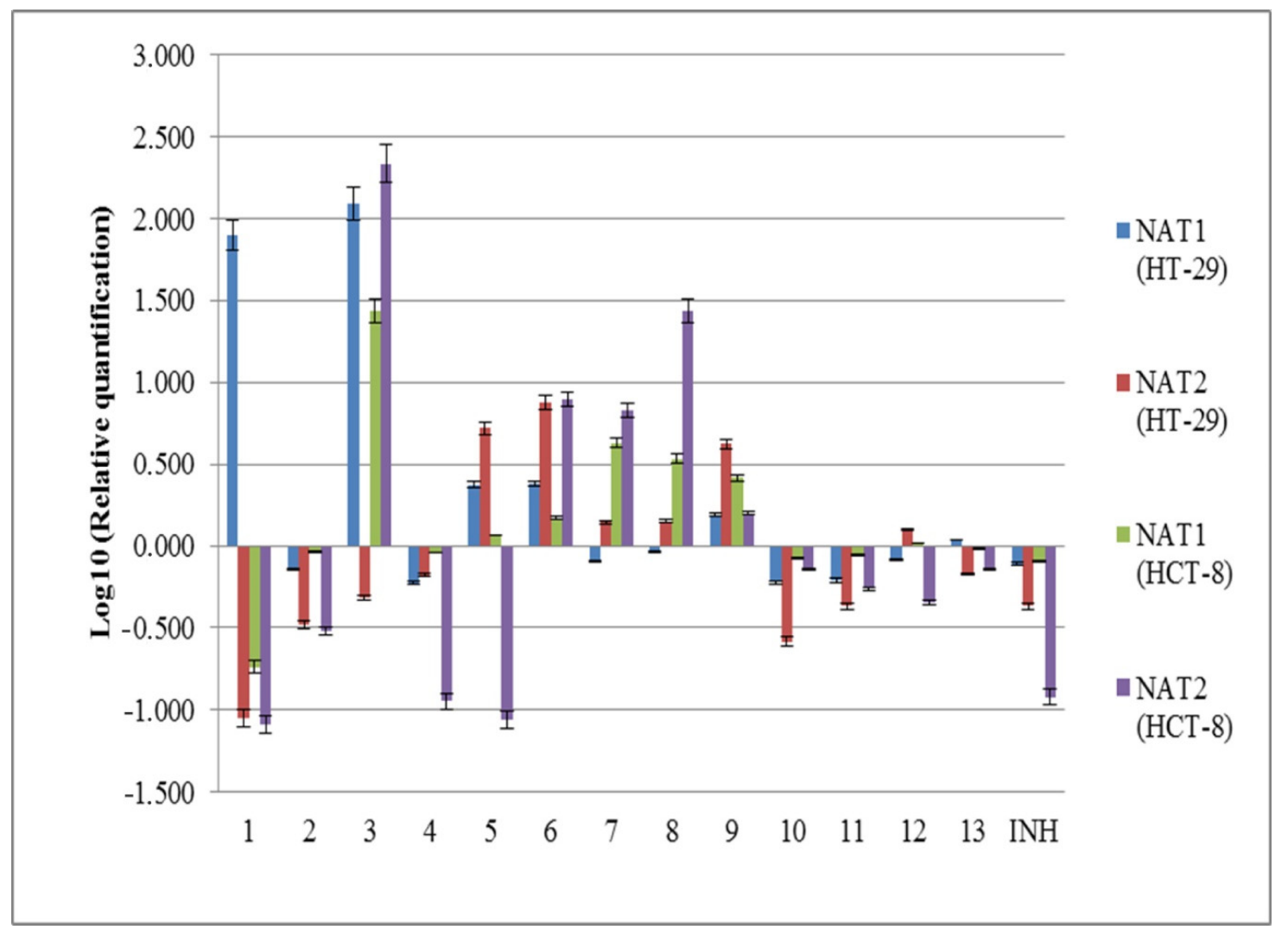

Figure 2. The influence of the new isoniazid derivatives 1-13 on the expression of NAT1 and NAT2 genes in HT-29 and HCT-8 cell lines.

In order to identify how new synthesized compounds may be degraded and eliminated from the body, the expression of some CYP450 isoenzymes, involved in the metabolism of pharmacological substances, was evaluated in HCT-8 and HT-29 cell lines (Figure 3). The obtained results shown that isoniazid decreased the expression of CYP1A1 and CYP2C19 genes in both cell lines, but increased the expression of CYP3A4 in HCT-8 cells. All tested compounds increased CYP1A1 expression in both cell lines, except for compound 3. Regarding the expression of $C Y P 2 C 19$, it was increased by 
compound 4 in both used cell lines; by compounds 1, 5, 6, 8, and 9 in HCT-8 cells; and by new synthesized 1,3,4-oxadiazoles 10, 11, 12, and $\mathbf{1 3}$ in HT-29 cells. CYP3A4 gene expression was increased by compounds 3 and $\mathbf{9}$ in HT-29 and in HCT- 8 cells, and by compounds 1, 2, and $\mathbf{4}$ only in HT-29 cells.



(A)

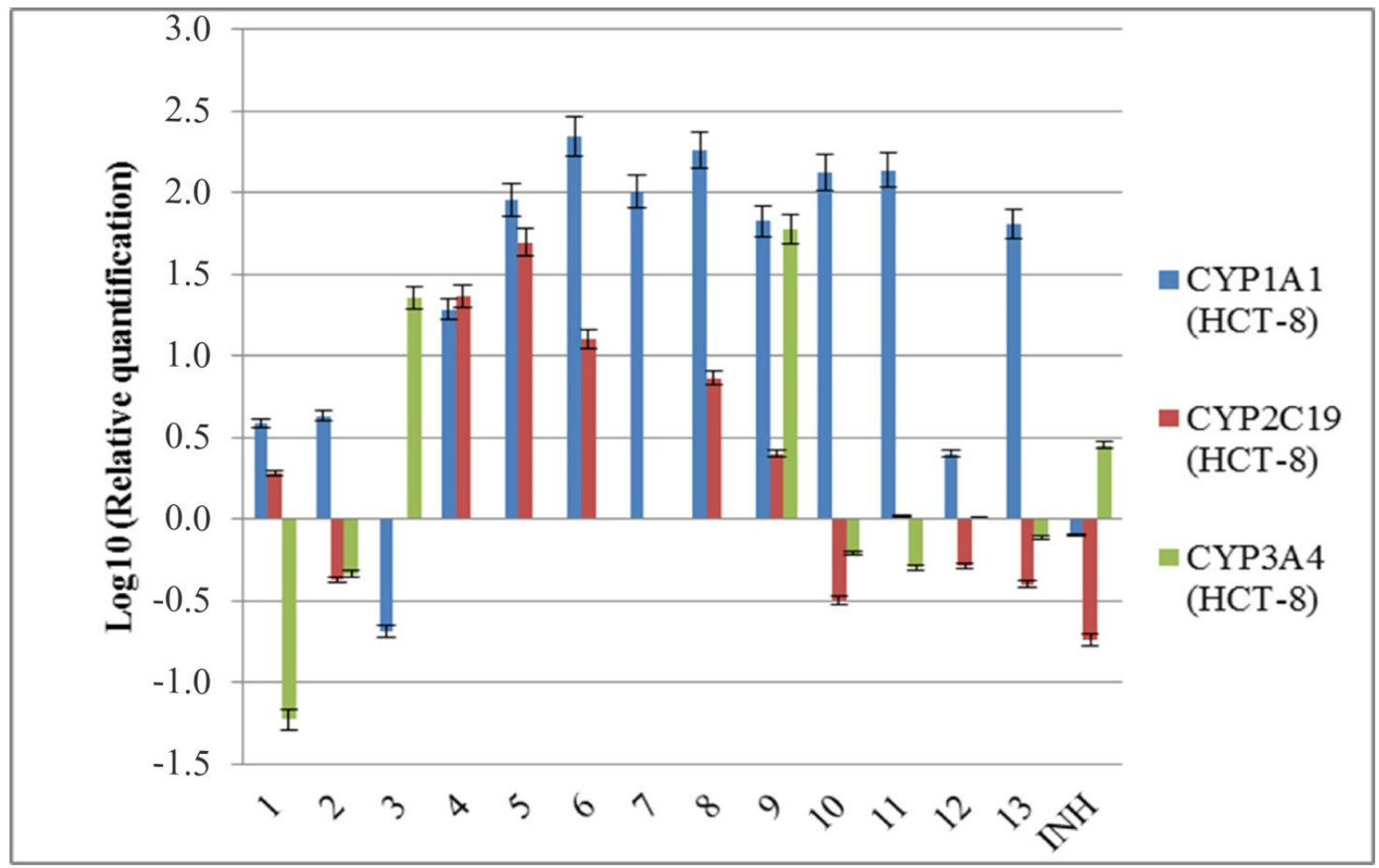

(B)

Figure 3. The influence of the new isoniazid derivatives 1-13 on the expression of CYP1A1, CYP2C19, and CYP3A4 genes in the eukaryotic cells; (A) HT-29 cells; (B) HCT-8 cells

Isoniazid inhibits CYP2C19 and CYP3A4 activities and mechanistically inactivates CYP1A2, $C Y P 2 A 6, C Y P 2 C 19$, and CYP3A4 in human liver microsomes [52,53]. El Sayed's group analyzed the 
influence of some isoniazid derivatives on the expression of mRNA and activity of enzymes implicated in drug metabolism in mice [54]. Although the analyzed compounds determined some changes in mRNA expressions, their influence on enzymes activity was minor [54]. The increased expression levels of CYP1A1 induced by the new synthesized isoniazid derivatives could be explained by the induction of their metabolism. CYP450 enzymes are implicated in phase I of xenobiotic and drug metabolism, and CYP1A1 catalyzes the hydroxylation and other oxidative transformations of aromatic substances [53,55]. Regarding different profiles of CYP2C19 expression in the two cell lines used, this could account for the existence of a polymorphic locus.

\subsubsection{Cytotoxicity and Effects on Cell Cycle}

The obtained compounds have also been tested to establish their cytotoxicity and the apoptotic effect on HT-29 cell line. The effect of the treatment with $50 \mu \mathrm{g} / \mathrm{mL}$ of substances for 24,48 , and $72 \mathrm{~h}$ was evaluated by flow cytometry using FITC-labeled annexin- $\mathrm{V}$ and propidium iodide staining that discriminate between apoptotic and intact cells. The most toxic compound proved to be compound 7 , followed by compounds 8 and $\mathbf{9}$. The treatment of HT-29 cells with $50 \mu \mathrm{g} / \mathrm{mL}$ of compound 7 has no toxic effect after $24 \mathrm{~h}$, but after 48 and $72 \mathrm{~h}$ it induced necrosis in $28.6 \%$ and $54 \%$, respectively, of the eukaryotic cells (Table 4).

Kumar's group evaluated a series of $N^{\prime}$-(E)-(substituted-benzylidene)-isonicotinohydrazide derivatives regarding their anticancer activity against several types of tumors and determined that isonicotinoyl hydrazides display moderate to potent anticancer activity [56]. Later, Rodrigues et al. evaluated thirty-two $N^{\prime}$-[(E)-(disubstituted-phenyl)-methylidene]-isonicotino-hydrazides for their activity against four human cancer cell lines and established that the biological activity of this compounds is determined by the number, the positions, and the types of substituents attached to the aromatic ring. The best results were proved by disubstituted derivatives, and the presence of hydroxyl groups on the benzene ring plays an important role in the anticancer activity of this series, especially when it is located in o-position. Hydroxyl groups located in o-position in hydrazone systems are good ligands for metals, the action mechanism of this class could possibly be based on the formation of complexes that are likely to inactivate enzymes involved in abnormal cell division [57].

In current case, the most cytotoxic activity had been proved by a compound containing a methyl group in $p$-position of a benzene ring (compound 7). This effect could be probably explained by its metabolism, the tolyl moiety being oxidized to the corresponding alcohol and carboxylic acid and to $o$-cresyl [58], the presence of hydroxyl groups on the benzene ring in o-position playing an important role in the anticancer activity [57]. The metabolic pathway of compound 9 possibly involves the oxidation of ethyl group resulting the corresponding alcohols and acids, which are less toxic [59]. In the case of compound 8, the major metabolic pathway could involve O-demethylation of this compound, similar to other compounds containing $p$-methoxyphenyl moiety [60], with isoniazid derivatives containing a hydroxyl moiety in the $p$-position of a benzene ring being less toxic [57].

The cytotoxicity of the newly synthesized compounds was also studied at the molecular level by analyzing the expression of genes implicated in apoptosis. From all tested substances, compounds 3 and 7 determined an increase in the expression levels of caspases 3, 7, 8, and 9 genes. Compounds $\mathbf{1 0}$ and $\mathbf{1 3}$ slightly increased the gene expression of caspases 3, 7, and 9, and compound 12 increased caspase 3 and 9 gene expression, while compounds 2, 8, and 9 increased only the expression of caspase 9 . Regarding the proapoptotic Bax (Bcl-2-associated X protein) and antiapoptotic Bcl-2 (B-cell lymphoma 2), their gene expression was increased by compounds 2, 10, and 12. Compound 13 increased Bcl-2 and decreased Bax gene expressions, while other tested compounds decreased both genes expressions. Still, the Bax/Bcl-2 ratio was positive accounting for an induction of apoptotic program. Regarding MCL1 (Myeloid Cell Leukemia Sequence 1), compounds 1, 2, 4, and 5 decreased expression of this gene, while the other compounds increased it (Figure 4). 
Table 4. Apoptosis induction by the new isoniazid derivatives in eukaryotic cells.

\begin{tabular}{|c|c|c|c|c|}
\hline Compound & $\begin{array}{c}\text { Necrosis } \\
{[\% \text { of Total Cells }]}\end{array}$ & $\begin{array}{l}\text { Late Apoptosis } \\
{[\% \text { of Total Cells }]}\end{array}$ & $\begin{array}{l}\text { Early Apoptosis } \\
{[\% \text { of Total Cells }]}\end{array}$ & $\begin{array}{c}\text { Viable Cells } \\
\text { [\% of Total Cells] }\end{array}$ \\
\hline \multicolumn{5}{|c|}{$72 \mathrm{~h}$} \\
\hline HT-29 & 1.46 & 0.206 & 0.057 & 98.3 \\
\hline INH & 5.25 & 3.09 & 0.915 & 90.7 \\
\hline 1 & 0.854 & 0.503 & 0.278 & 98.4 \\
\hline 2 & 0.493 & 0.937 & 0.305 & 98.3 \\
\hline 3 & 0.382 & 0.304 & 0.294 & 99.0 \\
\hline 4 & 11.1 & 1.85 & 2.15 & 84.9 \\
\hline 5 & 12.2 & 3.28 & 1.56 & 83 \\
\hline 6 & 5.82 & 2.7 & 1.01 & 90.5 \\
\hline 7 & 20.7 & 33.3 & 2.93 & 43 \\
\hline 8 & 8.38 & 7.05 & 1.99 & 82.6 \\
\hline 9 & 10.8 & 2.8 & 1.22 & 85.2 \\
\hline 10 & 0.766 & 0.317 & 0.196 & 98.7 \\
\hline 11 & 1.43 & 0.301 & 0.457 & 97.8 \\
\hline 12 & 0.553 & 0.82 & 0.23 & 98.4 \\
\hline 13 & 0.658 & 0.239 & 0.194 & 98.9 \\
\hline \multicolumn{5}{|c|}{$48 \mathrm{~h}$} \\
\hline HT-29 & 1.27 & 0.264 & 0.13 & 98.3 \\
\hline INH & 5.96 & 2.63 & 0.661 & 90.8 \\
\hline 1 & 2.35 & 0.325 & 0.337 & 97.0 \\
\hline 2 & 2.37 & 0.221 & 0.431 & 97.0 \\
\hline 3 & 0.706 & 0.121 & 0.538 & 98.6 \\
\hline 4 & 4.32 & 1.5 & 0.703 & 93.5 \\
\hline 5 & 5.19 & 4.35 & 1.17 & 89.3 \\
\hline 6 & 7.28 & 2.6 & 0.346 & 89.8 \\
\hline 7 & 16.2 & 12.4 & 0.736 & 70.7 \\
\hline 8 & 6.64 & 2.52 & 0.614 & 90.2 \\
\hline 9 & 10.1 & 4.52 & 0.708 & 84.6 \\
\hline 10 & 0.599 & 0.359 & 0.435 & 98.6 \\
\hline 11 & 3.15 & 0.834 & 0.337 & 95.7 \\
\hline 12 & 0.734 & 0.381 & 0.527 & 98.4 \\
\hline 13 & 0.732 & 0.174 & 0.131 & 99.0 \\
\hline \multicolumn{5}{|c|}{$24 \mathrm{~h}$} \\
\hline HT-29 & 0.68 & 0.032 & 0.404 & 98.9 \\
\hline INH & 3.68 & 1.85 & 1.06 & 93.4 \\
\hline 1 & 0.612 & 0.411 & 0.124 & 98.9 \\
\hline 2 & 0.637 & 0.505 & 0.204 & 98.7 \\
\hline 3 & 1.1 & 0.794 & 0.019 & 98.1 \\
\hline 4 & 5.58 & 0.964 & 0.832 & 92.6 \\
\hline 5 & 6.6 & 0.132 & 0.237 & 93 \\
\hline 6 & 4.88 & 1.2 & 1.14 & 92.8 \\
\hline 7 & 6.51 & 1.14 & 0.87 & 91.5 \\
\hline 8 & 4.22 & 1.71 & 1.95 & 92.1 \\
\hline 9 & 4.82 & 1.5 & 1.32 & 92.4 \\
\hline 10 & 0.835 & 0.169 & 0.129 & 98.9 \\
\hline 11 & 1.16 & 0.127 & 0.164 & 98.5 \\
\hline 12 & 1.15 & 0.816 & 0.11 & 97.9 \\
\hline 13 & 1.4 & 0.23 & 0.058 & 98.3 \\
\hline
\end{tabular}




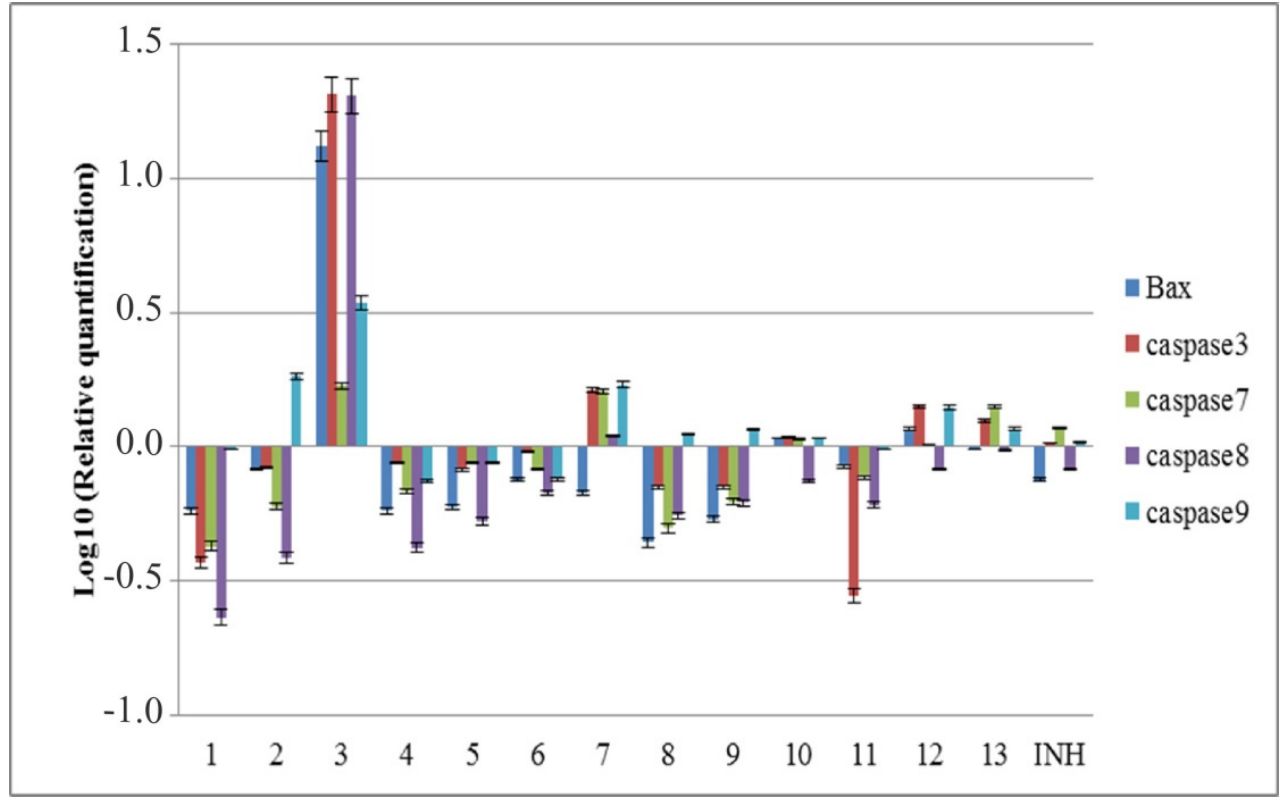

(A)

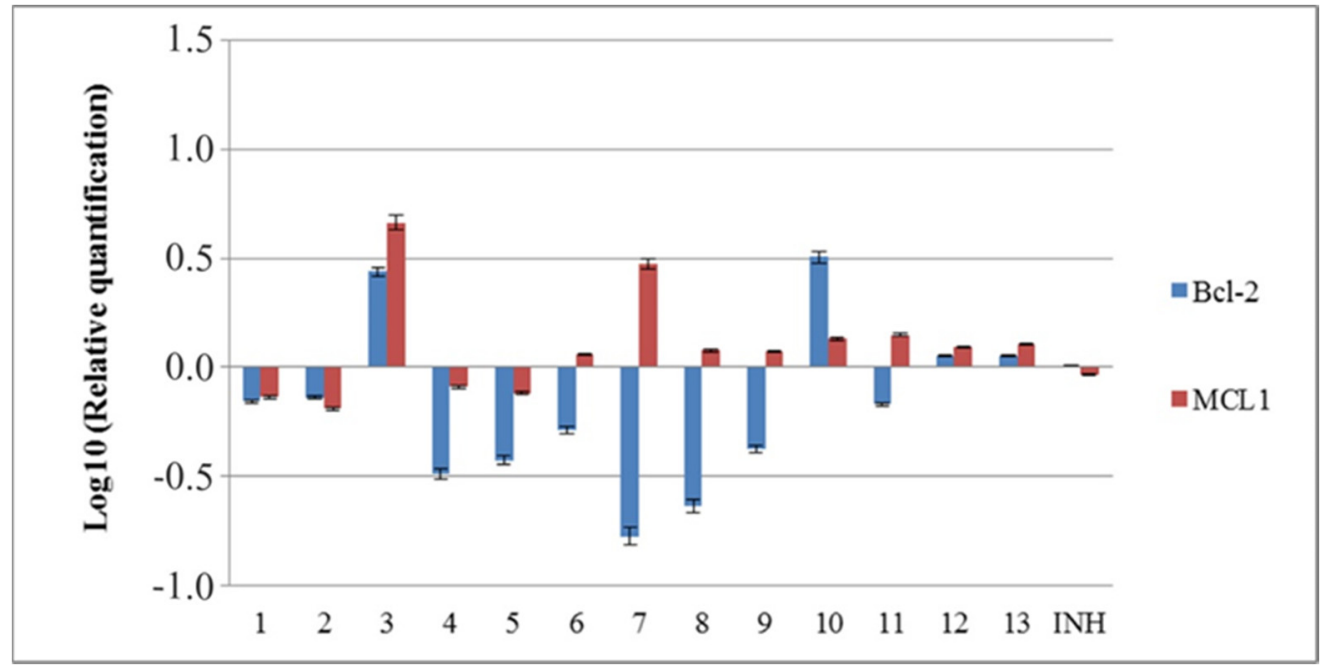

(B)

Figure 4. The influence of the new isoniazid derivatives on the expression of genes implicated in apoptosis induction in HCT-8 cells; (A) pro-apoptotic genes; (B) anti-apoptotic genes.

The activation of the effector caspase 3 can be induced by the extrinsic pathway via tumor necrosis factor (TNF) family receptors (e.g., Fas), FADD (Fas-activated death domain protein), and caspase 8 , or by the intrinsic pathway via the mitochondrial release of cytochrome $\mathrm{c}$ and Apaf-1-mediated processing of caspase 9 [61]. In the case of compound 7, the increased expression of caspase 9 could be associated with activation of intrinsic apoptotic pathway. Although the phenotypic changes induced by the treatment of compound 7 with $50 \mu \mathrm{g} / \mathrm{mL}$ for $24 \mathrm{~h}$ are minor, the increased expression of mRNA caspase 3 and 7 predicts the apoptotic phenomena occurring at 48 and $72 \mathrm{~h}$. In the case of compounds 3 , 12, and 13, although all evaluated caspases and Bax gene expressions were increased, the expression of antiapoptotic $B c l-2$ and MCL1 genes was also high, and no apoptotic effect was observed at 48 or $72 \mathrm{~h}$.

The influence of the new compounds on the cell cycle was determined on HCT-8 cells treated for $24 \mathrm{~h}$ with $50 \mu \mathrm{g} / \mathrm{mL}$ of the tested compounds. Compounds $\mathbf{4 - 9}$ and $\mathbf{1 3}$, containing methyl, ethyl, or methoxy moieties, increased the G0/G1 phase and decreased the $S$ phase, while the other compounds 
decreased the G0/G1 phase and increased the S phase. Compounds 4-6 slightly increased the G2/M phase, while the rest of compounds decreased this phase. $N, N, N^{\prime}$-Triacylhydrazines 7-9 exhibited a stronger influence on the cell cycle than the other tested compounds (Figure 5). The evaluation of the treatment at $48 \mathrm{~h}$ showed a decrease of $\mathrm{S}$ and G2/M phases in the case of $N, N, N^{\prime}$-triacylhydrazines 7 and 8 , and in addition, the appearance of the subG0 peak associated with apoptosis (Figure 6).

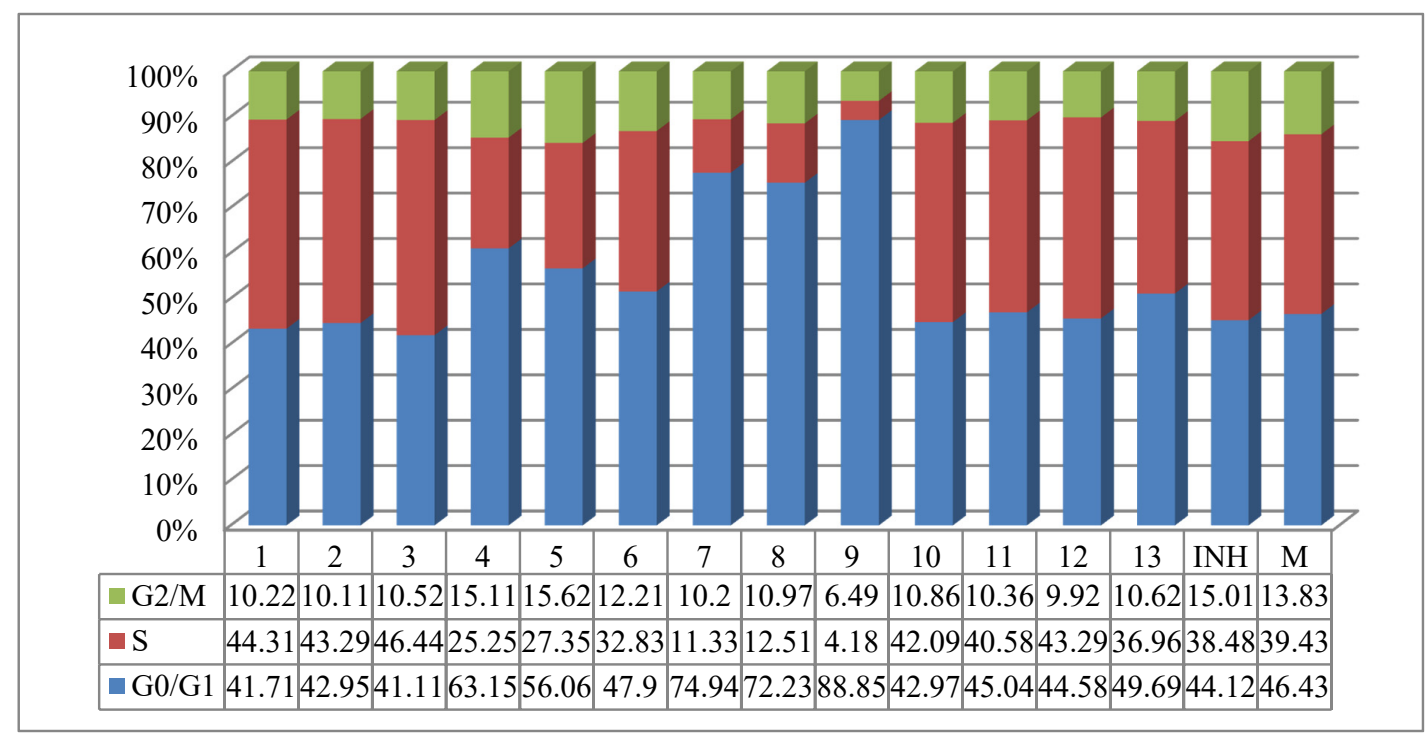

Figure 5. The influence of the new isoniazid derivatives on cell cycle in eukaryotic cells after a $24 \mathrm{~h}$ treatment.

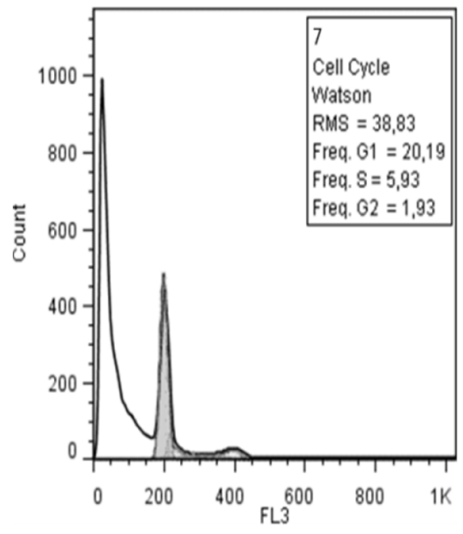

(A)

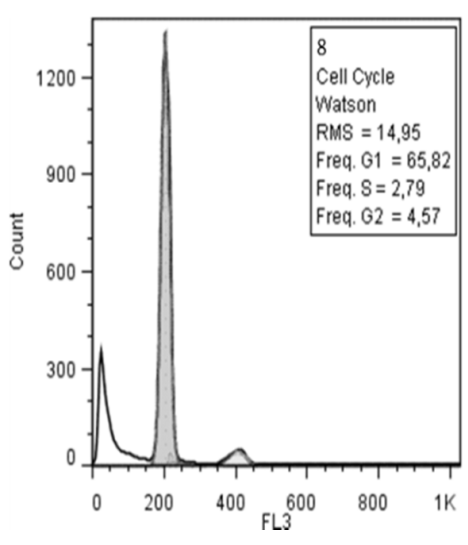

(B)

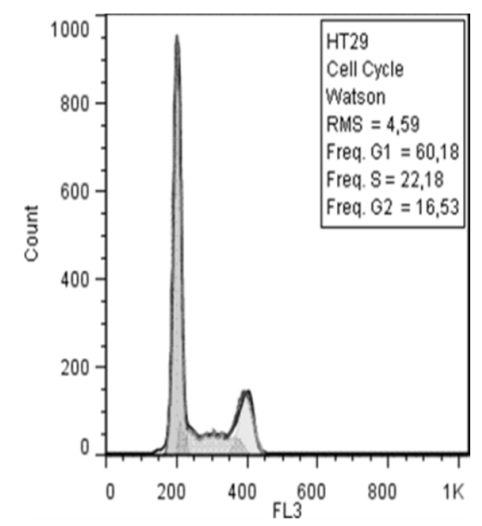

(C)

Figure 6. The influence of compounds 7 and 8 on the cell cycle in eukaryotic cells after a 48-h treatment: (A) compound 7; (B) compound 8; (C) control cells (HT 29).

At molecular level, the cell cycle is regulated by cyclin-dependent kinases (CDKs) that are activated by cyclins. In order to determine the influence of the tested compounds on the expression of different factors implicated in the regulation of the cell cycle, the expression of cyclin $A$, cyclin $B$, CDK1 (Cyclin-dependent kinase 1), and CDC20 (cell division cycle protein 20) genes was analyzed (Figure 7). Compounds 4 and 5 slightly reduced cyclin $A, C D K 1$, and CDC20 gene expression and induced the expression of the cyclin $B$ gene. Compounds $\mathbf{2}$ and $\mathbf{1 0}$ reduced cyclin $A$, cyclin $B$, and $C D C 20$ gene expression and induced the expression of the $C D K 1$ gene. Compound 6 proved to have a weak influence on the expression of genes implicated in the cell cycle by slightly increasing the expression of cyclin $A$, cyclin $B$, and $C D K 1$ genes and slightly reducing the expression of $C D C 20$. Compounds 1, 7, $\mathbf{8}, \mathbf{9}$, and 11 reduced the expression levels of cyclin $A$, cyclin $B, C D K 1$, and $C D C 20$ genes, indicating 
an inhibition of cell cycle progression, which is in agreement with the decrease of S and G2 phases demonstrated by flow cytometry. Compounds 3, 12, and 13 increased the evaluated genes expressions. The influence of these compounds on the gene expression of cyclin $B$ and CDK1 could explain no apoptotic effect observed disregard increased levels of expression of caspases. CDK1/cyclin B complex could phosphorylate procaspase 8 , inhibiting its processing and, thus, the activation of apoptosis through extrinsic pathway [62], and, also, could phosphorylate caspase 9 at an inhibitory site [63], consequently inhibiting the intrinsic apoptotic pathway. On the other hand, CDK1/cyclin B could also target p53, its Ser-315 phosphorylation enhancing ATP generation and membrane potential in mitochondria [64].

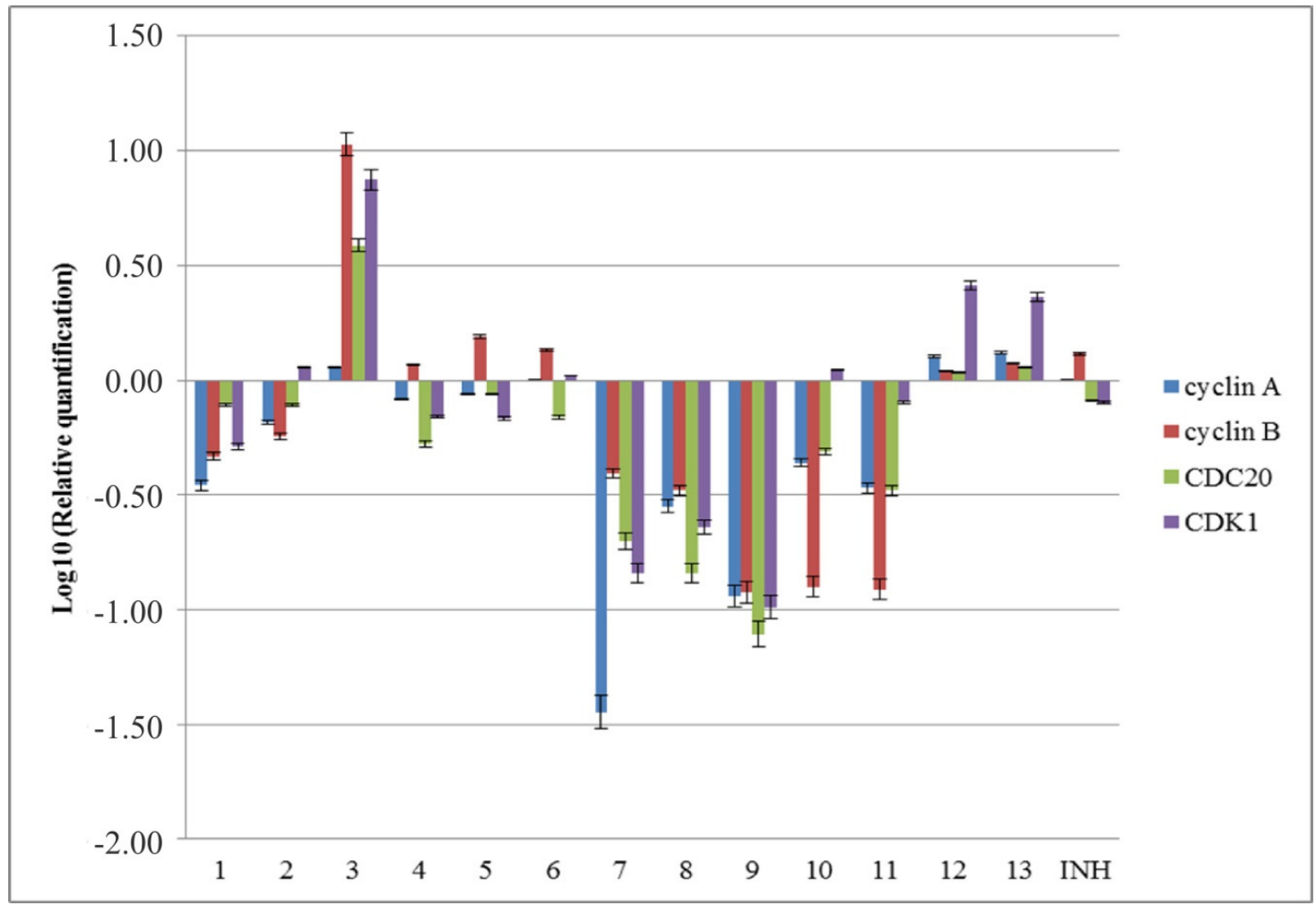

Figure 7. The influence of the new isoniazid derivatives 1-13 on the expression of cyclin $A$, cyclin $B$, $C D K 1$, and CDC20 genes in the eukaryotic cells.

The blocking in the G1 phase observed after $24 \mathrm{~h}$ of treatment with some isoniazid derivatives was previously reported in the literature [65]. The influence of these compounds on the cell cycle was explained by their activity as Fe-chelators, determining cyclin D proteolysis and cyclin E accumulation, and a decrease of CDK2 (Cyclin-dependent kinase 2) level [65,66].

In the current study, compounds 7-9 reduced the expression levels of genes implicated in S, G2, and $M$ phases of cell cycle and caused cell cycle blocking in G0/G1 phase. This effect can also be explained by their metabolism (discussed above), with presumed metabolites being capable of forming complexes that could inactivate enzymes involved in abnormal cell division [57].

The influence of compounds 7-9 on cell cycle indicates their antitumor potential and further studies on their mechanism of action should/will be done. 


\section{Materials and Methods}

\subsection{Chemicals and Analytical Techniques}

All chemicals and reagents were used as purchased from commercial suppliers (MilliporeSigma, Burlington, MA, USA and Chimopar, Bucharest, Romania, respectively) and were of the highest available purity. The solvents were used as absolute solvents, as well.

Analytical thin-layer chromatography (TLC) was performed on aluminium TLC plates that were silica gel-coated with fluorescent indicator F254, with size $20 \times 20 \mathrm{~cm}$, (Merck KGaA, Darmstadt, Germany). The spots were visualized using a fixed wavelength $(254 \mathrm{~nm}) \mathrm{UV}$ light.

The ${ }^{1} \mathrm{H}\left({ }^{13} \mathrm{C}\right)-\mathrm{NMR}$ spectra, in deuterated solvents DMSO- $\mathrm{d}_{6} / \mathrm{CDCl}_{3}$ (isotopic purity $99.9 \%$ ), were recorded on Varian Inova-400 NMR spectrometer (Agilent, Santa Clara, CA, USA, former Varian Inc., Palo Alto, CA, USA) of $400 \mathrm{MHz}\left({ }^{1} \mathrm{H}\right)$ and $100 \mathrm{MHz}\left({ }^{13} \mathrm{C}\right)$, equipped with a Varian broadband direct $\left({ }^{1} \mathrm{H} / \mathrm{X}\right)$ probe. The standard for chemical shift is tetramethylsilane (TMS) and J-values were calculated in Hz. Chemical shifts $\delta[\mathrm{ppm}]$ are referenced to protonated solvent signals as internal standard DMSO-d ${ }_{6}: \delta=2.50 \mathrm{ppm}\left({ }^{1} \mathrm{H}\right), 39.52 \mathrm{ppm}\left({ }^{13} \mathrm{C}\right)$, and $\mathrm{CDCl}_{3}: \delta=7.26 \mathrm{ppm}\left({ }^{1} \mathrm{H}\right), 77.16 \mathrm{ppm}\left({ }^{13} \mathrm{C}\right)[63-66]$. Signal multiplicities are abbreviated as $s$ (singlet), $d$ (doublet), $d d$ (doublet of doublet), $t$ (triplet), $d t$ (doublet of triplet), $q$ (quadruplet), and $m$ (multiplet) with the prefix $b$ in case of broad signals [67-70].

Molecular identification of organic functional groups in solid sample was performed by Fourier transform infrared spectroscopy using a Vertex 80v spectrometer (Bruker, Ettlingen, Germany), equipped with attenuated total reflectance (ATR) accessory. FTIR spectra were recorded in the range of 4000 to $400 \mathrm{~cm}^{-1}$, with $0.2 \mathrm{~cm}^{-1}$ spectral resolution, $0.1 \% \mathrm{~T}$ accuracy, and $32 \mathrm{scans} /$ spectra.

Melting points were determined on a melting point meter Krüss M5000 (A. Krüss Optronic, Hamburg, Germany), up to $400{ }^{\circ} \mathrm{C}$, and are given uncorrected.

Mass spectra were recorded on a Maxis Bruker $4 \mathrm{G}$ spectrometer (Bruker Corporation, Billerica, MA, USA) with an electrospray ionization source (ESI). For the biological approach, the synthetized compounds were initially dissolved in DMSO (i.e., $1 \mathrm{mg} / \mathrm{mL}$ ) to prepare a concentrated stock solution. Finally, additional dilutions (e.g., $1 \mu \mathrm{g} / \mathrm{mL}$ in methanol) were prepared in culture medium. The scanning range of molecular ions $(\mathrm{m} / \mathrm{z})$ was 50 to 1250 .

\subsection{Synthesis and Characterization of Isoniazid Derivatives}

\subsection{1. $N, N^{\prime}$-diacylhydrazines and $N, N, N^{\prime}$-triacylhydrazines}

To $5 \mathrm{mmol}$ of 2-(4-substituted-phenoxymethyl)-benzoic acid dissolved in $25 \mathrm{~mL}$ of 1,2-dichloroethan was added $10 \mathrm{mmol}$ of thionyl chloride. The mixture was refluxed for $3 \mathrm{~h}$. The excess of thionyl chloride and 1,2-dichloroethan was removed under reduced pressure. A quantity of $5 \mathrm{mmol}$ of isoniazid dissolved in $30 \mathrm{~mL}$ of dichloromethane was added to the crude acid chloride and the mixture was stirred overnight at room temperature. The next day, a double volume of water was added to the reaction mixture and the solid formed was separated by filtration and washed twice with dichloromethane. After filtration, the aqueous phase was extracted three times with dichloromethane and the organic layer was dried over anhydrous sodium sulfate. The solvent was removed under reduced pressure and the products (Figure 8) were separated and purified on chromatographic columns filled with silica gel using dichloromethane: ethyl acetate in gradient for elution. 

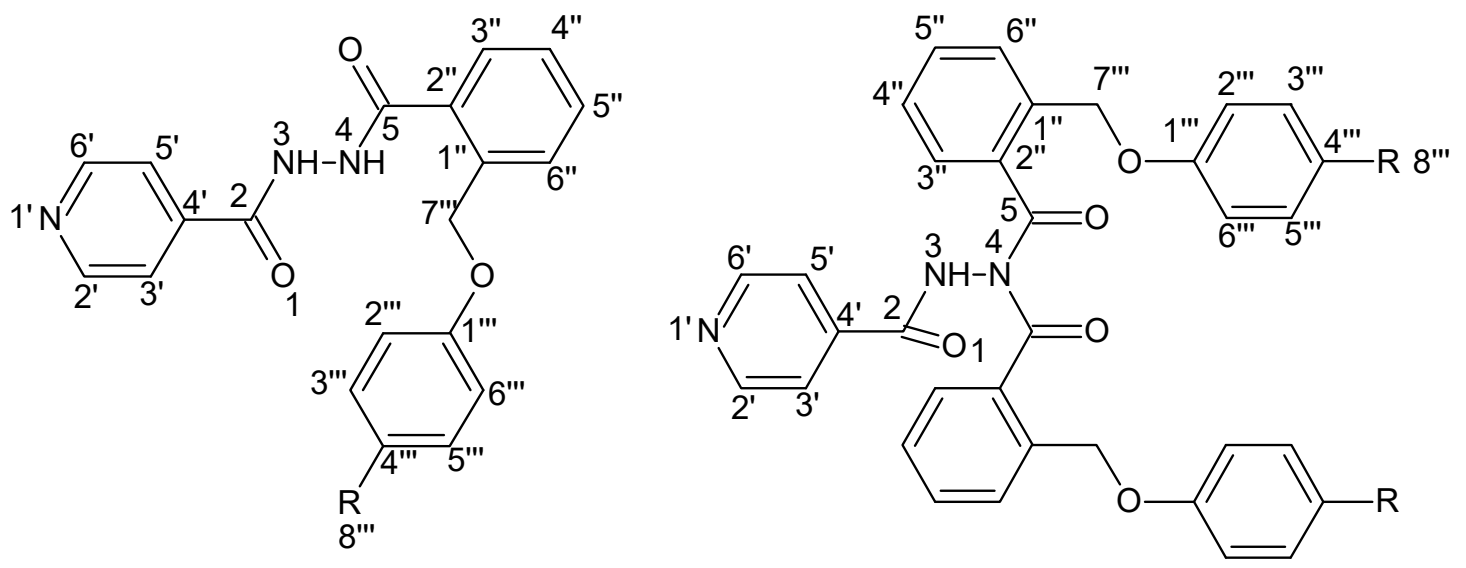

(A)

(B)

\begin{tabular}{cccccc}
\hline Compound & $\mathbf{R}$ & Compound & $\mathbf{R}$ & Compound & $\mathbf{R}$ \\
\hline 1 & $\mathrm{H}$ & 4 & $\mathrm{CH}_{3}$ & 7 & $\mathrm{CH}_{3}$ \\
2 & $\mathrm{~F}$ & 5 & $\mathrm{OCH}_{3}$ & 8 & $\mathrm{OCH}_{3}$ \\
3 & $\mathrm{Cl}$ & 6 & $\mathrm{C}_{2} \mathrm{H}_{5}$ & 9 & $\mathrm{C}_{2} \mathrm{H}_{5}$ \\
\hline
\end{tabular}

Figure 8. General formula of newly synthesized $N, N^{\prime}$-diacylhydrazines (compounds 1-6) (A) and $N, N, N^{\prime}$-triacylhydrazines (compounds 7-9) (B).

Compound 1

$N$-(2-Phenoxymethyl-benzoyl)- $N^{\prime}$-(isonicotinoyl)-hydrazine

Yield: $52 \%$

M.p.: $128-129^{\circ} \mathrm{C}$

Elemental analysis: $\mathrm{C}_{20} \mathrm{H}_{17} \mathrm{~N}_{3} \mathrm{O}_{3}, \mathrm{M}=347$; calcd: $\mathrm{C}=69.16 \%, \mathrm{H}=4.9 \%, \mathrm{~N}=12.1 \%$; found: $\mathrm{C}=69.14 \%, \mathrm{H}=4.93 \%, \mathrm{~N}=12.08 \%$.

${ }^{1} \mathrm{H}-\mathrm{NMR}\left(400 \mathrm{MHz}, \mathrm{DMSO}-\mathrm{d}_{6}, \delta \mathrm{ppm}, J \mathrm{~Hz}\right): 10.93$ (s, 1H, H-3), 10.52 (s, 1H, H-4), 8.89 (d, 2H, $\left.\mathrm{H}-2^{\prime}, \mathrm{H}-6^{\prime}, 5.9\right), 7.96\left(\mathrm{~d}, 1 \mathrm{H}, \mathrm{H}-3^{\prime \prime}, 7.4\right), 7.81\left(\mathrm{~d}, 2 \mathrm{H}, \mathrm{H}-3^{\prime}, \mathrm{H}-5^{\prime}, 6.0\right), 7.63\left(\mathrm{t}, 1 \mathrm{H}, \mathrm{H}-5^{\prime \prime}, 7.3\right), 7.54(\mathrm{~d}, 1 \mathrm{H}$, $\left.\mathrm{H}-6^{\prime \prime}, 7.8\right), 7.30\left(\mathrm{t}, 1 \mathrm{H}, \mathrm{H}-4^{\prime \prime}, 7.4\right), 7.34$ (t, $2 \mathrm{H}, \mathrm{H}-3^{\prime \prime \prime}, \mathrm{H}-5^{\prime \prime \prime}$, 8.0), 7.03-6.99 (m, 3H, H-2 $\left.{ }^{\prime \prime}, \mathrm{H}-4^{\prime \prime \prime}, \mathrm{H}-6^{\prime \prime \prime}\right)$, $5.21\left(\mathrm{~s}, 2 \mathrm{H}, \mathrm{H}-7^{\prime \prime \prime}\right)$.

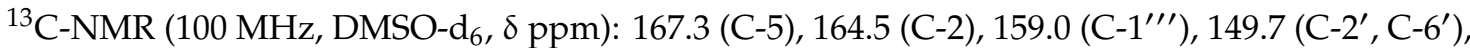
$140.8\left(\mathrm{C}-4^{\prime}\right), 136.5\left(\mathrm{C}-1^{\prime \prime}\right), 133.6\left(\mathrm{C}-2^{\prime \prime}\right), 132.3\left(\mathrm{C}-5^{\prime \prime}\right), 129.7\left(\mathrm{C}-3^{\prime \prime \prime}, \mathrm{C}-5^{\prime \prime \prime}\right), 128.5\left(\mathrm{C}-4^{\prime \prime}, 127.7\left(\mathrm{C}-3^{\prime \prime}\right)\right.$, $124.6\left(\mathrm{C}-6^{\prime \prime}\right), 121.7\left(\mathrm{C}-3^{\prime}, \mathrm{C}-5^{\prime}\right), 121.0\left(\mathrm{C}-4^{\prime \prime \prime}\right), 114.3\left(\mathrm{C}-2^{\prime \prime \prime}, \mathrm{C}-6^{\prime \prime \prime}\right), 68.5\left(\mathrm{C}-7^{\prime \prime \prime}\right)$.

FT-IR (ATR in solid, $v \mathrm{~cm}^{-1}$ ): 3199; 3030; 2915; 2468; 1672; 1607; 1588; 1547; 1510; 1455; 1282; 1240; $1140 ; 815 ; 742$.

HRMS $m / z 348.1346[\mathrm{M}+\mathrm{H}]^{+}$(calcd for $\mathrm{C}_{20} \mathrm{H}_{18} \mathrm{~N}_{3} \mathrm{O}_{3}{ }^{+}$: 348.1342).

$R_{f}$ (silicagel, AcOEt:MeOH = 9:1): 0.50.

Compound 2

$N$-[2-(p-Fluoro-phenoxymethyl)-benzoyl]- $N^{\prime}$-(isonicotinoyl)-hydrazine Yield: $40 \%$

M.p.: $168-169^{\circ} \mathrm{C}$

Elemental analysis: $\mathrm{C}_{20} \mathrm{H}_{16} \mathrm{FN}_{3} \mathrm{O}_{3}, \mathrm{M}=365$; calcd: $\mathrm{C}=65.75 \%, \mathrm{H}=4.38 \%, \mathrm{~N}=11.51 \%$; found: $\mathrm{C}=65.73 \%, \mathrm{H}=4.39 \%, \mathrm{~N}=11.53 \%$.

${ }^{1} \mathrm{H}-\mathrm{NMR}\left(400 \mathrm{MHz}, \mathrm{DMSO}-\mathrm{d}_{6}, \delta \mathrm{ppm}, J \mathrm{~Hz}\right): 10.98$ (s, 1H, H-3), 10.56 (s, 1H, H-4), 8.87 (d, 2H,

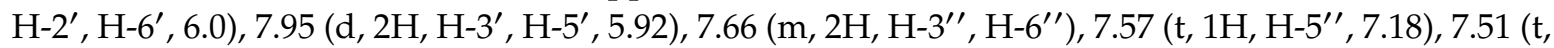

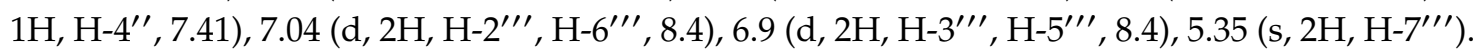


${ }^{13} \mathrm{C}-\mathrm{NMR}\left(100 \mathrm{MHz}, \mathrm{DMSO}-\mathrm{d}_{6}, \delta \mathrm{ppm}\right): 167.9$ (C-5), 164.2 (C-2), 162.1 (C-4"' $\left.{ }^{\prime \prime}\right), 156.4\left(\mathrm{C}-\mathrm{1}^{\prime \prime \prime}\right)$, $150.0\left(\mathrm{C}-2^{\prime}, \mathrm{C}-6^{\prime}\right), 140.8\left(\mathrm{C}-4^{\prime}\right), 136.5\left(\mathrm{C}-1^{\prime \prime}\right), 133.4\left(\mathrm{C}-2^{\prime \prime}\right), 131.1\left(\mathrm{C}-5^{\prime \prime}\right), 129.5\left(\mathrm{C}-4^{\prime \prime}\right), 127.5\left(\mathrm{C}-3^{\prime \prime}\right), 127.3$ $\left(\mathrm{C}-6^{\prime \prime}\right), 122.2\left(\mathrm{C}-3^{\prime}, \mathrm{C}-5^{\prime}\right), 116.2\left(\mathrm{C}-3^{\prime \prime \prime}, \mathrm{C}-5^{\prime \prime \prime}\right), 114.5\left(\mathrm{C}-2^{\prime \prime \prime}, \mathrm{C}-6^{\prime \prime \prime}\right), 66.5\left(\mathrm{C}-7^{\prime \prime \prime}\right)$.

FT-IR (ATR in solid, $v \mathrm{~cm}^{-1}$ ): 3242; 3037; 2923; 2451; 1689; 1598; 1581; 1524; 1443; 1237; 1134; 1114; $828 ; 739$.

HRMS $m / z 366.1248[\mathrm{M}+\mathrm{H}]^{+}$(calcd for $\mathrm{C}_{20} \mathrm{H}_{17} \mathrm{FN}_{3} \mathrm{O}_{3}{ }^{+}: 366.1248$ ).

$R_{f}$ (silicagel, AcOEt:MeOH = 9:1): 0.57.

Compound 3

$N$-[2-(p-Chloro-phenoxymethyl)-benzoyl]- $N^{\prime}$-(isonicotinoyl)-hydrazine Yield: 25\%

M.p.: $145-146^{\circ} \mathrm{C}$

Elemental analysis: $\mathrm{C}_{20} \mathrm{H}_{16} \mathrm{ClN}_{3} \mathrm{O}_{3}, \mathrm{M}=381.5$; calcd: $\mathrm{C}=62.91 \%, \mathrm{H}=4.19 \%, \mathrm{~N}=11.01 \%$; found: $\mathrm{C}=62.89 \%, \mathrm{H}=4.16 \%, \mathrm{~N}=11.03 \%$.

${ }^{1} \mathrm{H}-\mathrm{NMR}\left(400 \mathrm{MHz}, \mathrm{DMSO}-\mathrm{d}_{6}, \delta \mathrm{ppm}, J \mathrm{~Hz}\right): 11.2$ (s, 1H, H-3), 10.96 (s, 1H, H-4), 9.12 (d, 2H,



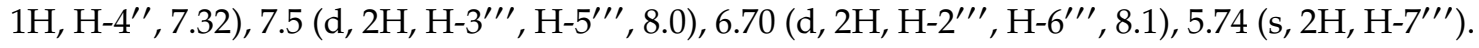

${ }^{13} \mathrm{C}-\mathrm{NMR}\left(100 \mathrm{MHz}, \mathrm{DMSO}-\mathrm{d}_{6}, \delta \mathrm{ppm}\right): 167.9$ (C-5), $164.4(\mathrm{C}-2), 156.6\left(\mathrm{C}-1^{\prime \prime \prime}\right), 150.1\left(\mathrm{C}-2^{\prime}, \mathrm{C}-6^{\prime}\right)$, $140.7\left(\mathrm{C}-4^{\prime}\right), 136.6\left(\mathrm{C}-1^{\prime \prime}\right), 133.7\left(\mathrm{C}-2^{\prime \prime}\right), 131.4\left(\mathrm{C}-5^{\prime \prime}\right), 125.1\left(\mathrm{C}-4^{\prime \prime \prime}\right), 129.9\left(\mathrm{C}-4^{\prime \prime}\right), 129.2\left(\mathrm{C}-3^{\prime \prime \prime}, \mathrm{C}-5^{\prime \prime \prime}\right)$, $128.2\left(\mathrm{C}-3^{\prime \prime}\right), 127.8\left(\mathrm{C}-6^{\prime \prime}\right), 122.2\left(\mathrm{C}-3^{\prime}, \mathrm{C}-5^{\prime}\right), 115.4\left(\mathrm{C}-2^{\prime \prime \prime}, \mathrm{C}-6^{\prime \prime \prime}\right), 67.1\left(\mathrm{C}-7^{\prime \prime \prime}\right)$.

FT-IR (ATR in solid, $v \mathrm{~cm}^{-1}$ ): 3215; 3037; 2968; 1690; 1598; 1573; 1510; 1452; 1247; 1218; 1139; 826; $741 ; 713$.

HRMS $m / z 382.0954[\mathrm{M}+\mathrm{H}]^{+}$(calcd for $\mathrm{C}_{20} \mathrm{H}_{17} \mathrm{ClN}_{3} \mathrm{O}_{3}{ }^{+}$: 382.0952).

$R_{f}$ (silicagel, AcOEt:MeOH = 9:1): 0.56 .

Compound 4

$\mathrm{N}$-[2-(p-Tolyloxymethyl)-benzoyl]-N'-(isonicotinoyl)-hydrazine Yield: $58 \%$

M.p.: $173-175^{\circ} \mathrm{C}$

Elemental analysis: $\mathrm{C}_{21} \mathrm{H}_{19} \mathrm{~N}_{3} \mathrm{O}_{3}, \mathrm{M}=361$; calcd: $\mathrm{C}=69.81 \%, \mathrm{H}=5.26 \%, \mathrm{~N}=11.63 \%$; found: $\mathrm{C}=69.83 \%, \mathrm{H}=5.25 \%, \mathrm{~N}=11.65 \%$.

${ }^{1} \mathrm{H}-\mathrm{NMR}\left(400 \mathrm{MHz}, \mathrm{DMSO}-\mathrm{d}_{6}, \delta \mathrm{ppm}, J \mathrm{~Hz}\right): 10.96$ (s, 1H, H-3), 10.55 (s, 1H, H-4), 8.84 (d, 2H,



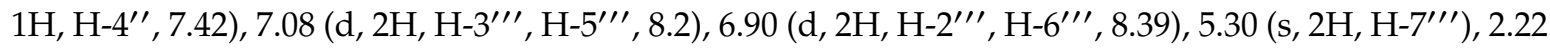
(s, 3H, H-8'" ).

${ }^{13} \mathrm{C}-\mathrm{NMR}\left(100 \mathrm{MHz}, \mathrm{DMSO}-\mathrm{d}_{6}, \delta \mathrm{ppm}\right): 167.5$ (C-5), 163.9 (C-2), $156.1\left(\mathrm{C}-1^{\prime \prime \prime}\right), 149.6\left(\mathrm{C}-2^{\prime}, \mathrm{C}-6^{\prime}\right)$, $140.2\left(\mathrm{C}-4^{\prime}\right), 136.0\left(\mathrm{C}-1^{\prime \prime}\right), 133.0\left(\mathrm{C}-2^{\prime \prime}\right), 130.5\left(\mathrm{C}-5^{\prime \prime}\right), 129.8\left(\mathrm{C}-4^{\prime \prime \prime}\right), 129.5\left(\mathrm{C}-4^{\prime \prime}\right), 127.8\left(\mathrm{C}-3^{\prime \prime \prime}, \mathrm{C}-5^{\prime \prime \prime}\right)$, $127.6\left(\mathrm{C}-3^{\prime \prime}\right), 127.5\left(\mathrm{C}-6^{\prime \prime}\right), 121.8\left(\mathrm{C}-3^{\prime}, \mathrm{C}-5^{\prime}\right), 114.6\left(\mathrm{C}-2^{\prime \prime \prime}, \mathrm{C}-6^{\prime \prime \prime}\right), 66.5\left(\mathrm{C}-7^{\prime \prime \prime}\right), 20.0\left(\mathrm{C}-8^{\prime \prime \prime}\right)$.

FT-IR (ATR in solid, $v \mathrm{~cm}^{-1}$ ): 3191; 3027; 2919; 2461; 1669; 1607; 1590; 1551; 1510; 1455; 1291; 1244; $1140 ; 811 ; 739$.

MS $m / z 362.1023[\mathrm{M}+\mathrm{H}]^{+}$(calcd for $\mathrm{C}_{21} \mathrm{H}_{20} \mathrm{~N}_{3} \mathrm{O}_{3}{ }^{+}: 362.4018$ ).

$R_{f}$ (silicagel, AcOEt: $\left.\mathrm{CH}_{2} \mathrm{Cl}_{2}=1: 1\right): 0.16$.

\section{Compound 5}

$N$-[2-(p-Methoxy-phenoxymethyl)-benzoyl]- $N^{\prime}$-(isonicotinoyl)-hydrazine Yield: 54\%

M.p.: $108-111^{\circ} \mathrm{C}$

Elemental analysis: $\mathrm{C}_{21} \mathrm{H}_{19} \mathrm{~N}_{3} \mathrm{O}_{4}, \mathrm{M}=377$; calcd: $\mathrm{C}=66.84 \%, \mathrm{H}=5.04 \%, \mathrm{~N}=11.17 \%$; found: $\mathrm{C}=66.82 \%, \mathrm{H}=5.02 \%, \mathrm{~N}=11.17 \%$.

${ }^{1} \mathrm{H}-\mathrm{NMR}\left(400 \mathrm{MHz}, \mathrm{CDCl}_{3}, \delta \mathrm{ppm}, J \mathrm{~Hz}\right): 10.11(\mathrm{~s}, 1 \mathrm{H}, \mathrm{H}-3), 9.72(\mathrm{~s}, 1 \mathrm{H}, \mathrm{H}-4), 8.63\left(\mathrm{~d}, 2 \mathrm{H}, \mathrm{H}-2^{\prime}\right.$, $\left.\mathrm{H}-6^{\prime}, 5.5\right), 7.74\left(\mathrm{~d}, 1 \mathrm{H}, \mathrm{H}-3^{\prime \prime}, 7.62\right), 7.62\left(\mathrm{~d}, 2 \mathrm{H}, \mathrm{H}-3^{\prime}, \mathrm{H}-5^{\prime}, 5.67\right), 7.52\left(\mathrm{~m}, 2 \mathrm{H}, \mathrm{H}-5^{\prime \prime}, \mathrm{H}-6^{\prime \prime}\right), 7.42(\mathrm{t}, 1 \mathrm{H}$, 


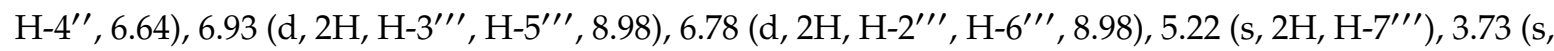
$\left.3 \mathrm{H}, \mathrm{H}-8^{\prime \prime \prime}\right)$.

${ }^{13} \mathrm{C}-\mathrm{NMR}\left(100 \mathrm{MHz}, \mathrm{CDCl}_{3}, \delta \mathrm{ppm}\right): 166.5$ (C-5), 162.8 (C-2), $154.7\left(\mathrm{C}-1^{\prime \prime \prime}\right), 152.2\left(\mathrm{C}-4^{\prime \prime \prime}\right), 150.6$ (C-2', C-6'), $138.5\left(\mathrm{C}-4^{\prime}\right), 135.7\left(\mathrm{C}-1^{\prime \prime}\right), 132.1\left(\mathrm{C}-2^{\prime \prime}\right), 131.8$ (C-3"'), $130.4\left(\mathrm{C}-5^{\prime \prime}\right), 129.0\left(\mathrm{C}-4^{\prime \prime}\right), 128.7$ $\left(\mathrm{C}-6^{\prime \prime}\right), 121.0\left(\mathrm{C}-3^{\prime}, \mathrm{C}-5^{\prime}\right), 116.61\left(\mathrm{C}-3^{\prime \prime \prime}, \mathrm{C}-5^{\prime \prime \prime}\right), 114.82\left(\mathrm{C}-2^{\prime \prime \prime}, \mathrm{C}-5^{\prime \prime \prime}\right), 69.55\left(\mathrm{C}-7^{\prime \prime \prime}\right), 55.72\left(\mathrm{C}-8^{\prime \prime \prime}\right)$.

FT-IR (ATR in solid, $v \mathrm{~cm}^{-1}$ ): 3199; 3066; 2993; 1683; 1592; 1576; 1550; 1452; 1242; 1213; 1140; 1038; 830; 743 .

MS $m / z 378.0935[\mathrm{M}+\mathrm{H}]^{+}$(calcd for $\mathrm{C}_{21} \mathrm{H}_{20} \mathrm{~N}_{3} \mathrm{O}_{4}{ }^{+}:$378.4012).

$R_{f}$ (silicagel, AcOEt: $\mathrm{CH}_{2} \mathrm{Cl}_{2}=1: 1$ ): 0.13 .

Compound 6

$N$-[2-(p-Ethyl-phenoxymethyl)-benzoyl]-N'-(isonicotinoyl)-hydrazine Yield: 33\%

M.p.: $133-135{ }^{\circ} \mathrm{C}$

Elemental analysis: $\mathrm{C}_{22} \mathrm{H}_{21} \mathrm{~N}_{3} \mathrm{O}_{3}, \mathrm{M}=375$; calcd: $\mathrm{C}=70.40 \%, \mathrm{H}=5.60 \%, \mathrm{~N}=11.20 \%$; found: $\mathrm{C}=70.36 \%, \mathrm{H}=5.62 \%, \mathrm{~N}=11.23 \%$.

${ }^{1} \mathrm{H}-\mathrm{NMR}\left(400 \mathrm{MHz}, \mathrm{DMSO}_{\mathrm{d}}, \delta \mathrm{ppm}, J \mathrm{~Hz}\right): 10.90$ (s, 1H, H-3), 10.53 (s, 1H, H-4), 8.78 (d, 2H,

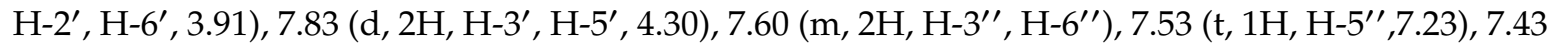


2.50 (m, 2H, overlapping with DMSO-d6 signal, H-8"' $), 1.11$ (t, 3H, H-9'" , 7.42).

${ }^{13} \mathrm{C}-\mathrm{NMR}\left(100 \mathrm{MHz}, \mathrm{DMSO}-\mathrm{d}_{6}, \delta \mathrm{ppm}\right): 167.6$ (C-5), 164.2 (C-2), $156.3\left(\mathrm{C}-1^{\prime \prime \prime}\right), 150.5\left(\mathrm{C}-2^{\prime}, \mathrm{C}-6^{\prime}\right)$, $139.4\left(\mathrm{C}-4^{\prime}\right), 136.1\left(\mathrm{C}-1^{\prime \prime}\right), 136.0\left(\mathrm{C}-4^{\prime \prime \prime}\right), 133.1\left(\mathrm{C}-2^{\prime \prime}\right), 130.6\left(\mathrm{C}-5^{\prime \prime}\right), 128.7\left(\mathrm{C}-4^{\prime \prime}\right), 127.9\left(\mathrm{C}-3^{\prime \prime \prime}, \mathrm{C}-5^{\prime \prime \prime}\right)$, $127.6\left(\mathrm{C}-3^{\prime \prime}\right), 127.6\left(\mathrm{C}-6^{\prime \prime}\right), 121.4\left(\mathrm{C}-3^{\prime}, \mathrm{C}-5^{\prime}\right), 114.7\left(\mathrm{C}-2^{\prime \prime \prime}, \mathrm{C}-2^{\prime \prime \prime}\right), 66.5\left(\mathrm{C}-7^{\prime \prime \prime}\right), 27.3\left(\mathrm{C}-8^{\prime \prime \prime}\right), 15.9\left(\mathrm{C}-9^{\prime \prime \prime}\right)$. FT-IR (ATR in solid, $v \mathrm{~cm}^{-1}$ ): 3265; 3030; 2961; 2926; 2870; 1690; 1608; 1581; 1509; 1453; 1218; 1140; $827 ; 736$.

MS $m / z 376.0836[\mathrm{M}+\mathrm{H}]^{+}$(calcd for $\mathrm{C}_{22} \mathrm{H}_{22} \mathrm{~N}_{3} \mathrm{O}_{3}{ }^{+}$: 376.3283).

$R_{f}$ (silicagel, AcOEt: $\mathrm{CH}_{2} \mathrm{Cl}_{2}=1: 1$ ): 0.17 .

\section{Compound 7}

$N, N$-di[2-(p-Tolyloxymethyl)-benzoyl]-N'-(isonicotinoyl)-hydrazine

Yield: $5 \%$

M.p.: semisolid

Elemental analysis: $\mathrm{C}_{36} \mathrm{H}_{31} \mathrm{~N}_{3} \mathrm{O}_{5}, \mathrm{M}=585$; calcd: $\mathrm{C}=73.85 \%, \mathrm{H}=5.30 \%, \mathrm{~N}=7.18 \%$; found: $\mathrm{C}=73.82 \%, \mathrm{H}=5.28 \%, \mathrm{~N}=7.19 \%$.

${ }^{1} \mathrm{H}-\mathrm{NMR}\left(400 \mathrm{MHz}, \mathrm{DMSO}_{-} \mathrm{d}_{6}, \delta \mathrm{ppm}, J \mathrm{~Hz}\right): 11.85$ (s, 1H, H-3), 8.77 (d, 2H, H-2' $\left.{ }^{\prime} \mathrm{H}-6^{\prime}, 5.86\right), 7.71$

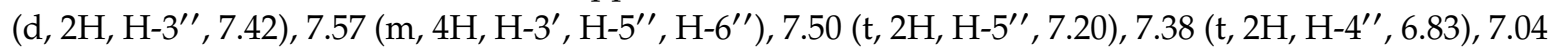

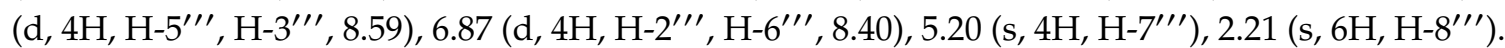

${ }^{13} \mathrm{C}-\mathrm{NMR}\left(400 \mathrm{MHz}, \mathrm{DMSO}-\mathrm{d}_{6}, \delta \mathrm{ppm}\right): 169.8(\mathrm{C}-5), 164.6$ (C-2), $155.9\left(\mathrm{C}-1^{\prime \prime \prime}\right), 150.5\left(\mathrm{C}-2^{\prime}, \mathrm{C}-6^{\prime}\right)$, $138.2\left(\mathrm{C}-4^{\prime}\right), 136.1\left(\mathrm{C}-1^{\prime \prime}\right), 132.6\left(\mathrm{C}-2^{\prime \prime}\right), 131.3\left(\mathrm{C}-5^{\prime \prime}\right), 129.7\left(\mathrm{C}-4^{\prime \prime \prime}\right), 129.5\left(\mathrm{C}-4^{\prime \prime}\right), 127.9\left(\mathrm{C}-3^{\prime}, \mathrm{C}-5^{\prime}\right), 127.4$ $\left(\mathrm{C}-3^{\prime \prime}\right), 127.2\left(\mathrm{C}-6^{\prime \prime}\right), 121.0\left(\mathrm{C}-3^{\prime \prime \prime}, \mathrm{C}-5^{\prime \prime \prime}\right), 114.6\left(\mathrm{C}-2^{\prime \prime \prime}, \mathrm{C}-6^{\prime \prime \prime}\right), 66.4\left(\mathrm{C}-7^{\prime \prime \prime}\right), 20.0\left(\mathrm{C}-8^{\prime \prime \prime}\right)$.

FT-IR (ATR in solid, $v \mathrm{~cm}^{-1}$ ): 3271; 3030; 2923; 1689; 1609; 1583; 1508; 1217; 1140; 811; 739.

MS $m / z 586.2167[\mathrm{M}+\mathrm{H}]^{+}$(calcd for $\mathrm{C}_{36} \mathrm{H}_{32} \mathrm{~N}_{3} \mathrm{O}_{5}{ }^{+}$: 586.5563).

$R_{f}$ (silicagel, AcOEt: $\mathrm{CH}_{2} \mathrm{Cl}_{2}=1: 1$ ): 0.60 .

\section{Compound 8}

$N, N$-di[2-(p-Methoxy-phenoxymethyl)-benzoyl]- $N^{\prime}$-(isonicotinoyl)-hydrazine

Yield: $2 \%$

M.p.: semisolid 
Elemental analysis: $\mathrm{C}_{36} \mathrm{H}_{31} \mathrm{~N}_{3} \mathrm{O}_{7}, \mathrm{M}=617$; calcd: $\mathrm{C}=70.02 \%, \mathrm{H}=5.02 \%, \mathrm{~N}=6.81 \%$; found: $\mathrm{C}=70.05 \%, \mathrm{H}=5.00 \%, \mathrm{~N}=6.79 \%$.

${ }^{1} \mathrm{H}-\mathrm{NMR}\left(400 \mathrm{MHz}, \mathrm{CDCl}_{3}, \delta \mathrm{ppm}, J \mathrm{~Hz}\right): 8.62$ (d, 2H, H-2' $\left.{ }^{\prime} \mathrm{H}-6^{\prime}, 5.47\right), 8.53$ (s, 1H, H-3), 7.69 (d, $\left.1 \mathrm{H}, \mathrm{H}-3^{\prime \prime}, 7.81\right), 7.55$ (d, 2H, H-6" , 7.62), 7.45 (t, 2H, H-5" , 7.48), 7.33 (t, 2H, H-4" , 7.61), 7.15 (d, 2H,

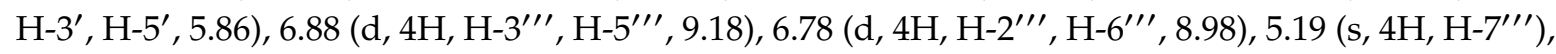
$3.72\left(\mathrm{~s}, 6 \mathrm{H}, \mathrm{H}-8^{\prime \prime \prime}\right)$.

${ }^{13} \mathrm{C}-\mathrm{NMR}\left(100 \mathrm{MHz}, \mathrm{CDCl}_{3}, \delta \mathrm{ppm}\right): 170.4$ (C-5), $164.4(\mathrm{C}-2), 154.4\left(\mathrm{C}-1^{\prime \prime \prime}\right), 152.4\left(\mathrm{C}-4^{\prime \prime \prime}\right), 150.5$ $\left(\mathrm{C}-2^{\prime}, \mathrm{C}-6^{\prime}\right), 138.7\left(\mathrm{C}-4^{\prime}\right), 135.5\left(\mathrm{C}-1^{\prime \prime}\right), 133.5\left(\mathrm{C}-2^{\prime \prime}\right), 131.4\left(\mathrm{C}-5^{\prime \prime}\right), 131.1\left(\mathrm{C}-4^{\prime \prime}\right), 128.7\left(\mathrm{C}-3^{\prime \prime}\right), 126.7\left(\mathrm{C}-6^{\prime \prime}\right)$, 120.8 (C-3', C-5'), $116.8\left(\mathrm{C}-3^{\prime \prime \prime}, \mathrm{C}-5^{\prime \prime \prime}\right), 114.9\left(\mathrm{C}-2^{\prime \prime \prime}{ }^{\prime \prime}, \mathrm{C}-6^{\prime \prime \prime}\right), 68.6\left(\mathrm{C}-7^{\prime \prime \prime}\right), 55.7\left(\mathrm{C}-8^{\prime \prime \prime}\right)$.

FT-IR (ATR in solid, $v \mathrm{~cm}^{-1}$ ): 3267; 3065; 2932; 1688; 1556; 1503; 1463; 1207; 1139; 1032; 821; 737.

MS $m / z 618.2467[\mathrm{M}+\mathrm{H}]^{+}$(calcd for $\mathrm{C}_{36} \mathrm{H}_{32} \mathrm{~N}_{3} \mathrm{O}_{7}{ }^{+}$: 618.5551).

$R_{f}$ (silicagel, AcOEt: $\mathrm{CH}_{2} \mathrm{Cl}_{2}=1: 1$ ): 0.52 .

\section{Compound 9}

$N, N$-di[2-(p-Ethyl-phenoxymethyl)-benzoyl]- $N^{\prime}$-(isonicotinoyl)-hydrazine

Yield: $6 \%$

M.p.: semisolid

Elemental analysis: $\mathrm{C}_{38} \mathrm{H}_{35} \mathrm{~N}_{3} \mathrm{O}_{5}, \mathrm{M}=613$; calcd: $\mathrm{C}=74.39 \%, \mathrm{H}=5.71 \%, \mathrm{~N}=6.85 \%$; found: $\mathrm{C}=74.37 \%, \mathrm{H}=5.69 \%, \mathrm{~N}=6.87 \%$.

${ }^{1} \mathrm{H}-\mathrm{NMR}$ (DMSO, $\delta$ ppm, J Hz): 11.97 (s, 1H, H-3), 8.77 (d, 2H, H-2' , H-6' 4.69 ), 7.73 (d, 2H, $\left.\mathrm{H}-3^{\prime \prime}, 7.62\right), 7.58$ (m, 4H, H-3' $\left.{ }^{\prime} \mathrm{H}-5^{\prime}, \mathrm{H}-6^{\prime \prime}\right), 7.50$ (t, $\left.2 \mathrm{H}, \mathrm{H}-5^{\prime \prime}, 7.42\right), 7.37$ (t, $\left.2 \mathrm{H}, \mathrm{H}-4^{\prime \prime}, 7.03\right), 7.07$ (d, $4 \mathrm{H}$,

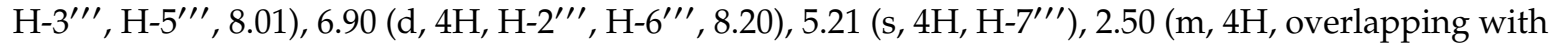
DMSO-d6 signal, $\left.\mathrm{H}-8^{\prime \prime \prime}\right), 1.12\left(\mathrm{t}, 6 \mathrm{H}, \mathrm{H}-9^{\prime \prime \prime}, 7.43\right)$.

${ }^{13}$ C-NMR (DMSO, 8 ppm): 169.9 (C-5), 164.7 (C-2), 156.1 (C-1'”'), 150.5 (C-2' , C-6'), 138.5 (C-4'), $136.1\left(\mathrm{C}-1^{\prime \prime}\right), 132.7\left(\mathrm{C}-4^{\prime \prime \prime}\right), 131.2\left(\mathrm{C}-2^{\prime \prime}\right), 129.6\left(\mathrm{C}-5^{\prime \prime}\right), 128.6\left(\mathrm{C}-4^{\prime \prime}\right), 128.0\left(\mathrm{C}-3^{\prime \prime \prime}, \mathrm{C}-5^{\prime \prime \prime}\right), 127.4\left(\mathrm{C}-3^{\prime \prime}\right)$, 127.2 (C-6" $\left.{ }^{\prime \prime}\right), 121.1\left(\mathrm{C}-3^{\prime}, \mathrm{C}-5^{\prime}\right), 114.6\left(\mathrm{C}-2^{\prime \prime \prime}, \mathrm{C}-6^{\prime \prime \prime}\right), 66.4\left(\mathrm{C}-7^{\prime \prime \prime}\right), 27.3\left(\mathrm{C}-8^{\prime \prime \prime}\right), 15.8\left(\mathrm{C}-9^{\prime \prime \prime}\right)$.

FT-IR (ATR in solid, $v \mathrm{~cm}^{-1}$ ): 3231; 3022; 2958; 2923; 1674; 1628; 1599; 1554; 1507; 1476; 1244; 1134; $831 ; 748$.

MS $m / z 614.0954[\mathrm{M}+\mathrm{H}]^{+}$(calcd for $\mathrm{C}_{38} \mathrm{H}_{36} \mathrm{~N}_{3} \mathrm{O}_{5}{ }^{+}$: 614.3095).

$R_{f}$ (silicagel, AcOEt: $\mathrm{CH}_{2} \mathrm{Cl}_{2}=1: 1$ ): 0.63 .

\subsubsection{1,3,4-Oxadiazoles Synthesis}

A quantity of $1 \mathrm{mmol} N, N^{\prime}$-diacylhydrazine was suspended in $15 \mathrm{~mL}$ toluene. After $20 \mathrm{~min}$ of stirring, $5 \mathrm{mmol}$ phosphoryl chloride was added dropwise. The reaction mixture was refluxed for $6 \mathrm{~h}$ and stirred overnight at room temperature. The solvent and residual phosphoryl chloride were removed under reduced pressure. The residue was taken up in dichloromethane and washed three times with $5 \% \mathrm{NaOH}$ solution and three times with saturated aqueous $\mathrm{NaCl}$ solution. The organic layer was dried over anhydrous sodium sulfate and distilled under reduced pressure to remove the solvent. The final compound (Figure 9) was recrystallized using ethanol. 


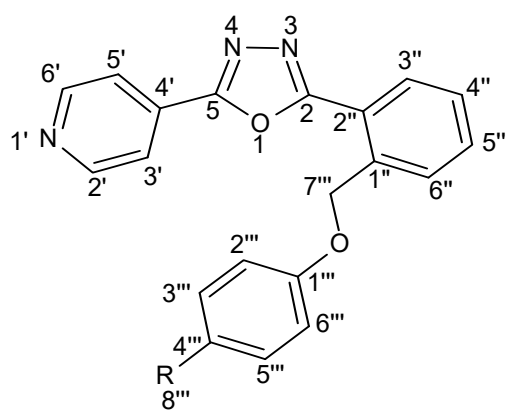

\begin{tabular}{cc} 
Comp. & $\mathbf{R}$ \\
\hline 10 & $\mathrm{H}$ \\
11 & $\mathrm{~F}$ \\
12 & $\mathrm{Cl}$ \\
13 & $\mathrm{CH}_{3}$ \\
\hline
\end{tabular}

Figure 9. General formula of newly synthesized 1,3,4-oxadiazoles (compounds 10-13).

Compound 10

22-[2-(Phenoxymethyl)-phenyl]-5-(pyridine-4-yl)-1,3,4-oxadiazole

Yield: $62 \%$

M.p.: $210-211^{\circ} \mathrm{C}$

Elemental analysis: $\mathrm{C}_{20} \mathrm{H}_{15} \mathrm{~N}_{3} \mathrm{O}_{2}, \mathrm{M}=329$; calcd: $\mathrm{C}=72.95 \%, \mathrm{H}=4.56 \%, \mathrm{~N}=12.77 \%$; found: $\mathrm{C}=72.97 \%, \mathrm{H}=4.58 \%, \mathrm{~N}=12.74 \%$.

${ }^{1} \mathrm{H}-\mathrm{NMR}(400 \mathrm{MHz}$, DMSO-d6, $\delta$ ppm, J Hz): 8.87 (d, 2H, H-2' , H-6' , 4.00), 8.24 (d, 1H, H-3" ,

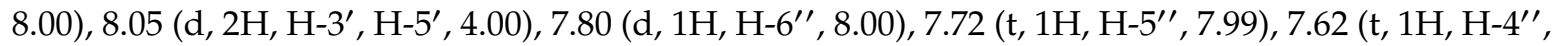




$136.7\left(\mathrm{C}-4^{\prime}\right), 132.3\left(\mathrm{C}-5^{\prime \prime}\right), 132.0\left(\mathrm{C}-2^{\prime \prime}\right), 130.4\left(\mathrm{C}-4^{\prime \prime}\right), 129.6\left(\mathrm{C}-3^{\prime \prime \prime}, \mathrm{C}-5^{\prime \prime \prime}\right), 129.2\left(\mathrm{C}-6^{\prime \prime}\right), 128.6\left(\mathrm{C}-3^{\prime \prime}\right)$, $121.4\left(\mathrm{C}-1^{\prime \prime}\right), 121.1\left(\mathrm{C}-4^{\prime \prime \prime}\right), 120.0\left(\mathrm{C}-3^{\prime}, \mathrm{C} 5^{\prime}\right), 114.5\left(\mathrm{C}-2^{\prime \prime \prime}, \mathrm{C}-6^{\prime \prime \prime}\right), 67.6\left(\mathrm{C}-7^{\prime \prime \prime}\right)$.

FT-IR (ATR in solid, $v \mathrm{~cm}^{-1}$ ): 3030; 2964; 2815; 2160; 1604; 1574; 1552; 1503; 1452; 1232; 1125; 1015 ; $824 ; 742$.

HRMS $m / z 330.1237[\mathrm{M}+\mathrm{H}]^{+}$(calcd for $\mathrm{C}_{20} \mathrm{H}_{16} \mathrm{~N}_{3} \mathrm{O}_{2}{ }^{+}: 330.1237$ ).

$R_{f}$ (silicagel, AcOEt:MeOH = 9:1): 0.72 .

Compound 11

22-[2-(p-Fluoro-phenoxymethyl)-phenyl]-5-(pyridine-4-yl)-1,3,4-oxadiazole

Yield: $65 \%$

M.p.: $298-299^{\circ} \mathrm{C}$

Elemental analysis: $\mathrm{C}_{20} \mathrm{H}_{14} \mathrm{FN}_{3} \mathrm{O}_{2}, \mathrm{M}=347$; calcd: $\mathrm{C}=69.16 \%, \mathrm{H}=4.03 \%, \mathrm{~N}=12.1 \%$; found: $\mathrm{C}=69.15 \%, \mathrm{H}=4.05 \%, \mathrm{~N}=12.12 \%$.

${ }^{1} \mathrm{H}-\mathrm{NMR}(400 \mathrm{MHz}, \mathrm{DMSO}-\mathrm{d} 6, \delta$ ppm, $J \mathrm{~Hz}): 8.74$ (d, 2H, H-2' , H-6' , 4.68), 8.21 (d, 1H, H-3' , 7.3),



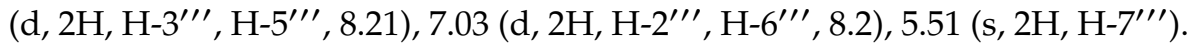

${ }^{13} \mathrm{C}-\mathrm{NMR}(100 \mathrm{MHz}, \mathrm{DMSO}-\mathrm{d6}, \delta \mathrm{ppm}): 164.9$ (C-5), 162.8 (C-2), $156.6\left(\mathrm{C}-1^{\prime \prime \prime}\right), 152.1\left(\mathrm{C}-4^{\prime \prime \prime}\right)$, $151.3\left(\mathrm{C}-2^{\prime}, \mathrm{C}-6^{\prime}\right), 137.2\left(\mathrm{C}-4^{\prime}\right), 132.5\left(\mathrm{C}-5^{\prime \prime}\right), 131.0\left(\mathrm{C}-2^{\prime \prime}\right), 129.9\left(\mathrm{C}-1^{\prime \prime}\right), 129.8\left(\mathrm{C}-3^{\prime \prime}\right), 129.5\left(\mathrm{C}-6^{\prime \prime}\right), 129.0$ $\left(\mathrm{C}-4^{\prime \prime}\right), 120.7\left(\mathrm{C}-3^{\prime}, \mathrm{C} 5^{\prime}\right), 115.2\left(\mathrm{C}-3^{\prime \prime \prime}, \mathrm{C}-5^{\prime \prime \prime}\right), 114.9\left(\mathrm{C}-2^{\prime \prime \prime}, \mathrm{C}-6^{\prime \prime \prime}\right), 68.3\left(\mathrm{C}-7^{\prime \prime \prime}\right)$.

FT-IR (ATR in solid, $v \mathrm{~cm}^{-1}$ ): 3029; 2974; 2844; 2163; 1608; 1581; 1508; 1455; 1241; 1124; 1114; 1015; $841 ; 739$.

HRMS m/z $348.1145[\mathrm{M}+\mathrm{H}]^{+}$(calcd for $\mathrm{C}_{20} \mathrm{H}_{15} \mathrm{FN}_{3} \mathrm{O}_{2}{ }^{+}:$348.1142).

$R_{f}$ (silicagel, AcOEt:MeOH = 9:1): 0.79. 


\section{Compound 12}

22-[2-(p-Chloro-phenoxymethyl)-phenyl]-5-(pyridine-4-yl)-1,3,4-oxadiazole

Yield: $68 \%$

M.p.: $341-342^{\circ} \mathrm{C}$

Elemental analysis: $\mathrm{C}_{20} \mathrm{H}_{14} \mathrm{ClN}_{3} \mathrm{O}_{2}, \mathrm{M}=363.5$; calcd: $\mathrm{C}=66.02 \%, \mathrm{H}=3.85 \%, \mathrm{~N}=11.55 \%$; found: $\mathrm{C}=66.01 \%, \mathrm{H}=3.87 \%, \mathrm{~N}=11.57 \%$.

${ }^{1} \mathrm{H}-\mathrm{NMR}(400 \mathrm{MHz}, \mathrm{DMSO}-\mathrm{d} 6, \delta \mathrm{ppm}, J \mathrm{~Hz}): 8.71$ (d, 2H, H-2' , H-6', 4.68), 8.14 (d, 1H, H-3" , 7.3),

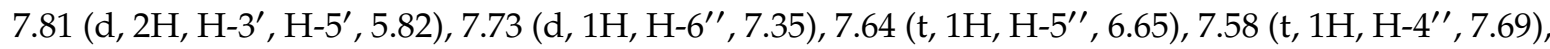

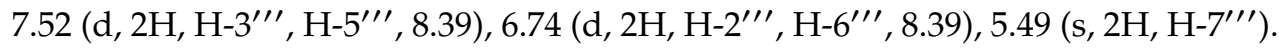

${ }^{13} \mathrm{C}-\mathrm{NMR}(100 \mathrm{MHz}, \mathrm{DMSO}-\mathrm{d} 6, \delta \mathrm{ppm}): 164.1$ (C-5), 161.9 (C-2), $155.9\left(\mathrm{C}-1^{\prime \prime \prime}\right), 150.3\left(\mathrm{C}-2^{\prime}, \mathrm{C}-6^{\prime}\right)$, $136.5\left(\mathrm{C}-4^{\prime}\right), 132.0\left(\mathrm{C}-5^{\prime \prime}\right), 130.4\left(\mathrm{C}-2^{\prime \prime}\right), 129.4\left(\mathrm{C}-1^{\prime \prime}\right), 129.2\left(\mathrm{C}-3^{\prime \prime}\right), 129.0\left(\mathrm{C}-6^{\prime \prime}\right), 128.7\left(\mathrm{C}-3^{\prime \prime \prime}, \mathrm{C}-5^{\prime \prime \prime}\right)$, $128.1\left(\mathrm{C}-4^{\prime \prime}\right), 124.8\left(\mathrm{C}-4^{\prime \prime \prime}\right), 120.0\left(\mathrm{C}-3^{\prime}, \mathrm{C} 5^{\prime}\right), 114.8\left(\mathrm{C}-2^{\prime \prime \prime}, \mathrm{C}-6^{\prime \prime \prime}\right), 67.7\left(\mathrm{C}-7^{\prime \prime \prime}\right)$.

FT-IR (ATR in solid, $v \mathrm{~cm}^{-1}$ ): 3030; 2991; 2843; 2159; 1604; 1582; 1551; 1510; 1455; 1218; 1125; 840; $745 ; 713$.

HRMS m/z 364.0837 [M + H] $]^{+}$(calcd for $\mathrm{C}_{20} \mathrm{H}_{15} \mathrm{ClN}_{3} \mathrm{O}_{2}{ }^{+}:$364.2827).

$R_{f}$ (silicagel, AcOEt:MeOH = 9:1): 0.75 .

Compound 13

22-[2-(p-Tolyloxymethyl)-phenyl]-5-(pyridine-4-yl)-1,3,4-oxadiazole

Yield: $73 \%$

M.p.: $249-250{ }^{\circ} \mathrm{C}$

Elemental analysis: $\mathrm{C}_{21} \mathrm{H}_{17} \mathrm{~N}_{3} \mathrm{O}_{2}, \mathrm{M}=343$; calcd: $\mathrm{C}=73.47 \%, \mathrm{H}=4.96 \%, \mathrm{~N}=12.24 \%$; found: $\mathrm{C}=73.45 \%, \mathrm{H}=4.93 \%, \mathrm{~N}=12.27 \%$.

${ }^{1} \mathrm{H}-\mathrm{NMR}(400 \mathrm{MHz}, \mathrm{DMSO}-\mathrm{d} 6, \delta \mathrm{ppm}, J \mathrm{~Hz}): 8.79$ (d, 2H, H-2' $\left., \mathrm{H}-6{ }^{\prime}, 4.71\right), 8.22$ (d, 1H, H-3' $\left.{ }^{\prime \prime}, 7.29\right)$, 7.89 (d, 2H, H-3' , H-5', 5.73), 7.78 (d, 1H, H-6" , 7.40), 7.70 (t, 1H, H-5' , 6.63), $7.62\left(\mathrm{t}, 1 \mathrm{H}, \mathrm{H}-4^{\prime \prime}, 7.69\right)$,

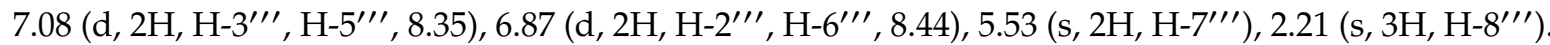

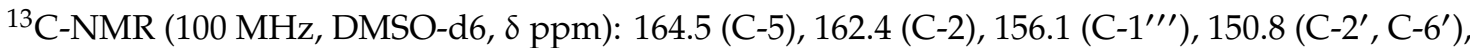
$136.8\left(\mathrm{C}-4^{\prime}\right), 132.2\left(\mathrm{C}-5^{\prime \prime}\right), 130.4\left(\mathrm{C}-2^{\prime \prime}\right), 129.9\left(\mathrm{C}-3^{\prime \prime \prime}, \mathrm{C}-5^{\prime \prime \prime}\right), 129.6\left(\mathrm{C}-1^{\prime \prime}\right), 129.5\left(\mathrm{C}-3^{\prime \prime}\right), 129.1\left(\mathrm{C}-6^{\prime \prime}\right)$, $128.5\left(\mathrm{C}-4^{\prime \prime}\right), 121.4\left(\mathrm{C}-4^{\prime \prime \prime}\right), 120.2\left(\mathrm{C}-3^{\prime}, \mathrm{C}^{\prime}\right), 114.5\left(\mathrm{C}-2^{\prime \prime \prime}, \mathrm{C}-6^{\prime \prime \prime}\right), 67.7\left(\mathrm{C}-7^{\prime \prime \prime}\right), 20.1\left(\mathrm{C}-8^{\prime \prime \prime}\right)$.

FT-IR (ATR in solid, $v \mathrm{~cm}^{-1}$ ): 3028; 2924; 2870; 2158; 1608; 1587; 1550; 1509; 1457; 1240; 1125; $810 ; 735$.

HRMS m/z $344.1394[\mathrm{M}+\mathrm{H}]^{+}$(calcd for $\mathrm{C}_{21} \mathrm{H}_{18} \mathrm{~N}_{3} \mathrm{O}_{2}{ }^{+}:$344.3465).

$R_{f}$ (silicagel, $\mathrm{CH}_{2} \mathrm{Cl}_{2}: \mathrm{MeOH}=5: 1$ ): 0.60 .

\subsection{Anti-Mycobacterial Activity}

The M. tuberculosis clinical strain used for anti-mycobacterial assay was maintained on Middlebrook 7H9 broth. The anti-mycobacterial activity was evaluated by the microplate Alamar Blue assay (MABA) as stated by Franzblau et al. [71]. We used serial dilutions of the new synthesized compounds and isoniazid, the final drug concentrations being between $25 \mu \mathrm{g} / \mathrm{mL}$ to $0.012 \mu \mathrm{g} / \mathrm{mL}$. Equal volumes of M. tuberculosis inoculum and tested compounds were mixed and incubated at $37^{\circ} \mathrm{C}$ for eight days in 96-well plates covered and sealed with parafilm. On day nine, a volume of $10 \mu \mathrm{L}$ of freshly prepared mixture (1:1) of Alamar Blue reagent $(0.1 \mathrm{mg} / \mathrm{mL})$ and tween $80(10 \%)$ was added to each well and kept at $37^{\circ} \mathrm{C}$ for another $24 \mathrm{~h}$. A blue color in the well was interpreted as no bacterial growth, and a pink color was scored as growth. The MIC (Minimal Inhibition Concentration) was defined as the lowest drug concentration, which prevented a color change from blue to pink. 


\subsection{Antibacterial Activity}

The antimicrobial activity of the newly synthesized compounds was determined according to Matei et al. [51], using the following strains: Acinetobacter baumanii, Citrobacter koseri, Escherichia coli, Enterobacter cloacae, Enterococcus faecalis, Klebsiella pneumonia, Morganella morganii, Pseudomonas aeruginosa, Peudomonas putida, Salmonella typhimurium, Serratia marcescens, Shigella sonnei, Stenotrophomonas maltophilia, Staphylococcus hominis, Staphylococcus aureus, and coagulase-negative staphylococci, using an adapted agar disk diffusion technique. Briefly, bacterial suspensions of 0.5 McFarland density obtained from $24 \mathrm{~h}$ cultures were seed on solid medium. Subsequent, a volume of $5 \mu \mathrm{L}$ of tested compounds ( $1 \mathrm{mg} / \mathrm{mL}$ solutions) were spotted on inoculated plates. Anti-bacterial activity was assessed after incubation for $24 \mathrm{~h}$ at $37^{\circ} \mathrm{C}$.

\subsection{Cell Culture}

Two cell lines, HCT-8 (CCL-224) and HT-29 (ATCC-HTB-38), were used to evaluate the activity of new compounds on eukaryotic cells. These cells were maintained as adherent cultures in Dulbecco's Modified Essential Medium (DMEM) (Sigma, Ronkonkoma, NY, USA) supplemented with 10\% heat-inactivated fetal bovine serum (Sigma, USA) at $37^{\circ} \mathrm{C}, 5 \% \mathrm{CO}_{2}$, in a humid atmosphere.

\subsection{Apoptosis Detection}

The apoptotic effect of tested compounds was evaluated using Annexin V-FITC Apoptosis Detection Kit I (BD Bioscience Pharmingen, USA) according to manufacturer protocol. In this regard, HT-29 cells $\left(3 \times 10^{6}\right)$, were seeded in $3.5 \mathrm{~cm}$ diameter wells and treated with $50 \mu \mathrm{g} / \mathrm{mL}$ of tested compounds. After $24 \mathrm{~h}$, the cells were resuspended in $100 \mu \mathrm{L}$ of binding buffer and stained with $5 \mu \mathrm{L}$ Annexin V-FITC and $5 \mu \mathrm{L}$ propidium iodide for $10 \mathrm{~min}$ in dark. At least 10,000 events from each sample were acquired using a Beckman Coulter flow cytometer. The analysis was done using FlowJo $\mathrm{v}$ 8.8.6 software (Ashland, OR, USA).

\subsection{Cell Cycle Analysis}

To assess the influence of new compounds on cell cycle, a number of $3 \times 10^{6}$ HT-29 cells were treated with compounds at $50 \mu \mathrm{g} / \mathrm{mL}$ concentration for $24 \mathrm{~h}$. Treated cells were harvested, washed in a cold phosphate-buffered saline solution (PBS), then fixed in cold ethanol $(70 \%)$ and stored at $-20{ }^{\circ} \mathrm{C}$. After $24 \mathrm{~h}$, the cells were washed with PBS, resuspended in $100 \mu \mathrm{l}$ PBS, treated with $1 \mathrm{mg} / \mathrm{mL}$ RNase A and labeled with $100 \mu \mathrm{g} / \mathrm{mL}$ propidium iodide in the dark at room temperature for $30 \mathrm{~min}$. DNA content of cells was quantified on a Beckman Coulter EPICS XL flow cytometer and analyzed using FlowJo 8.8.6 software (Ashland, OR, USA).

\subsection{Quantitative RT-PCR for Analysis of Genes Expression}

A number of $3 \times 10^{6}$ HT-29 or HCT-8 cells treated with isoniazid and compounds 1-13 at final concentration of $50 \mu \mathrm{g} / \mathrm{mL}$ for $24 \mathrm{~h}$ were used to extract total RNA with Trizol Reagent (Invitrogen, USA) as indicated in the protocol. For each sample, $2 \mu \mathrm{g}$ of total RNA was reverse transcripted using High Capacity cDNA Reverse Transcription Kit with RNAse inhibitor (Applied Biosystem). Following, $50 \mathrm{ng}$ of cDNA from each sample was used in real-time PCR reaction that was performed on an ABI 7300 Real Time PCR System. Gene expression was evaluated using pre-validated Taqman Gene Expression Assays (Applied Biosystems) for NAT1 (Hs00265080_s1), NAT2 (Hs01854954_s1), BAX (Hs00180269_m1), MCL1 (Hs00172036_m1), BCL2 (Hs00153350_m1), CASP3 (Hs00234387_m1), CASP7 (Hs00169152_m1), CASP8 (Hs00154256_m1), CASP9 (Hs00154261_m1), CCNB1 (Hs00259126_m1), CDK1 (Hs00938777_m1), CCNA2 (Hs00153138_m1), CDC20 (Hs00426680_mH) as well as human beta actin (endogenous control). Also, for CYP1A1, CYP2C19, CYP3A4 and GAPDH (endogenous control), forward and reverse primers were used as described by Matei et al. [51]. Results were analyzed with RQ study software (Applied Biosystems) applying $\Delta \Delta \mathrm{C}_{\mathrm{T}}$ method. 


\section{Conclusions}

Starting from isoniazid, six new $N, N^{\prime}$-diacylhydrazines were obtained, together with three new $N, N, N^{\prime}$-triacylhydrazines ones; also, the $N, N^{\prime}$-diacylhydrazines were converted by synthesis in the corresponding new oxadiazoles. All the compounds were characterized by IR, NMR, MS, and elemental analysis. The newly obtained derivatives of isoniazid exhibit different biological activities, depending on their structure. The best antioxidant and antibacterial activities (including anti-Mycobacterium tuberculosis effects) were proved by compound 9. Compounds 7-9 determined cell cycle blocking in G0/G1 phase. Moreover, compound 7 proved to be the most toxic, inducing apoptosis in $54 \%$ of cells after $72 \mathrm{~h}$, an effect that can be predicted by the increased expression of mRNA caspase 3 and 7 after a $24 \mathrm{~h}$ treatment. The influence of tested compounds on gene expression of some enzymes implicated in drug metabolism indicate that newly synthesized compounds could be metabolized on other pathways than NAT2, spanning adverse effects of isoniazid.

In summary, compound 9 had the best antibacterial activity and could be used as disinfectant agent, and, along with compounds 7 and 8, seemed to have antitumor potential. Further studies of action mechanism of these compounds on cell cycle may bring some new significant information regarding their activity potential.

Author Contributions: Conceptualization, I.Z., L.M., P.I., C.B., and C.L.; methodology, I.Z., L.M., C.B., P.I., A.T., A.P., and I.N.; software, I.N. and A.H.; validation, P.I., A.T., and I.Z.; investigation, L.M., C.B., P.I., A.T., A.P., I.N., A.H., C.C.D., C.L., D.C.N., R.M.N., and I.Z.; resources, A.T., C.C.D. and C.L.; data curation, L.M., C.B., and I.Z.; writing-original draft preparation, I.Z., L.M., and C.R.; writing-review and editing, I.Z., L.M., C.B., C.C.D., and C.R.; visualization, I.Z. and P.I.; supervision, I.Z.; project administration, C.R.; funding acquisition, C.R. All authors have read and agreed to the published version of the manuscript.

Funding: This research was funded by projects: CNFIS-FDI-0397 Performanţă şi excelenţă în cercetarea multidisciplinară (PerExcel) (Performance and excellence in multidisciplinary research) 2020 and Competitiveness Operational Programme (COP) A1.1.4. ID: P_37_798 MyeloAL-EDiaProT, Contract 149/26.10.2016, (SMIS: 106774), MyeloAL Project.

Conflicts of Interest: The authors declare no conflict of interest.

\section{References}

1. Mcnaught, A.D.; Wilkinson, A. Compendium of Chemical Terminology: IUPAC Recommendations, 2nd ed.; Blackwell Science: Oxford, UK, 1997.

2. Reichelt, A.; Falsey, J.R.; Rzasa, R.M.; Thiel, O.R.; Achmatowicz, M.M.; Larsen, R.D.; Zhang, D. Palladium-catalyzed chemoselective monoarylation of hydrazides for the synthesis of [1,2,4] triazolo [4,3-a] pyridines. Org Lett. 2010, 12, 792-795. [CrossRef]

3. Abd Alla, M.S.; Hegab, M.I.; Abo Taleb, N.A.; Hasabelnaby, S.M.; Goudah, A. Synthesis and anti-inflammatory evaluation of some condensed [4-(3,4-dimethylphenyl)-1(2H)-oxo-phthalazin-2-yl] acetic acid hydrazide. Eur. J. Med. Chem. 2010, 45, 1267-1277. [CrossRef] [PubMed]

4. Chandrakantha, B.; Shetty, P.; Nambiyar, V.; Isloor, N.; Isloor, A.M. Synthesis, characterization and biological activity of some new 1,3,4-oxadiazole bearing 2-flouro-4-methoxy phenyl moiety. Eur. J. Med. Chem. 2010, 45, 1206-1210. [CrossRef] [PubMed]

5. Toliwal, S.; Jadav, K.; Patel, K. Synthesis and Biological Evaluation of Fatty Hydrazides of By-products of Oil Processing Industry. Indian J. Pharm. Sci. 2009, 71, 144-148. [CrossRef] [PubMed]

6. Mohareb, R.M.; Fleita, D.H.; Sakka, O.K. Novel synthesis of hydrazide-hydrazone derivatives and their utilization in the synthesis of coumarin, pyridine, thiazole and thiophene derivatives with antitumor activity. Molecules 2011, 16, 16-27. [CrossRef] [PubMed]

7. Husain, A. Amide derivatives of sulfonamides and isoniazid: Synthesis and biological evaluation. Acta Pol. Pharm. 2009, 66, 513-521. [PubMed]

8. Almasirad, A.; Hosseini, R.; Jalalizadeh, H.; Rahimi-Moghaddam, Z.; Abaeian, N.; Janafrooz, M.; Abbaspour, M.; Ziaee, V.; Dalvandi, A.; Shafiee, A. Synthesis and analgesic activity of 2-phenoxybenzoic acid and N-phenylanthranilic acid hydrazides. Biol. Pharm. Bull. 2006, 29, 1180-1185. [CrossRef] 
9. Joshi, S.; Khosla, N.; Tiwari, P. In vitro study of some medicinally important Mannich bases derived from antitubercular agent. Bioorg. Med. Chem. 2004, 12, 571-576. [CrossRef]

10. Zhao, H.; Neamati, N.; Sunder, S.; Hong, H.; Wang, S.; Milne, G.W.; Pommier, Y.; Burke, T.R., Jr. Hydrazide-containing inhibitors of HIV-1 integrase. J. Med. Chem. 1997, 40, 937-941. [CrossRef]

11. Bhat, K.I.; Sufeera, K.; Chaitanya Sunil Kumar, P. Synthesis, Characterization and Biological Activity Studies of 1,3,4-Oxadiazole Analogs. J. Young Pharm. 2011, 3, 310. [CrossRef]

12. Salahuddin, A.; Mazumder, M.; Yar, M.S.; Mazumder, R.; Chakraborthy, G.S.; Ahsan, M.J.; Rahman, M.U. Updates on synthesis and biological activities of 1,3,4-oxadiazole: A review. Synth. Commun. 2017, 47, 1805-1847. [CrossRef]

13. Donald, P.R.; Sirgel, F.A.; Botha, F.J.; Seifart, H.I.; Parkin, D.P.; Vandenplas, M.L.; van de Wal, B.W.; Maritz, J.S.; Mitchison, D.A. The early bactericidal activity of isoniazid related to its dose size in pulmonary tuberculosis. Am. J. Respir. Crit. Care Med. 1997, 156, 895-900. [CrossRef]

14. Donald, P.R.; Sirgel, F.A.; Venter, A.; Parkin, D.P.; Seifart, H.I.; Van De Wal, B.W.; Werely, C.; Van Helden, P.D.; Maritz, J.S. The influence of human N-acetyltransferase genotype on the early bactericidal activity of isoniazid. Clin. Infect. Dis. 2004, 39, 1425-1430. [CrossRef] [PubMed]

15. Karakousis, P.C.; Williams, E.P.; Bishai, W.R. Altered expression of isoniazid-regulated genes in drug-treated dormant Mycobacterium tuberculosis. J. Antimicrob. Chemother. 2008, 61, 323-331. [CrossRef]

16. Bardou, F.; Raynaud, C.; Ramos, C.; Laneelle, M.A.; Laneelle, G. Mechanism of isoniazid uptake in Mycobacterium tuberculosis. Microbiology 1998, 144, 2539-2544. [CrossRef] [PubMed]

17. Zhang, Y.; Heym, B.; Allen, B.; Young, D.; Cole, S. The catalase-peroxidase gene and isoniazid resistance of Mycobacterium tuberculosis. Nature 1992, 358, 591-593. [CrossRef]

18. Davidson, L.A.; Takayama, K. Isoniazid inhibition of the synthesis of monounsaturated long-chain fatty acids in Mycobacterium tuberculosis H37Ra. Antimicrob. Agents Chemother. 1979, 16, 104. [CrossRef]

19. Argyrou, A.; Vetting, M.W.; Aladegbami, B.; Blanchard, J.S. Mycobacterium tuberculosis dihydrofolate reductase is a target for isoniazid. Nat. Struct. Mol. Biol. 2006, 13, 408-413. [CrossRef]

20. Timmins, G.S.; Master, S.; Rusnak, F.; Deretic, V. Requirements for nitric oxide generation from isoniazid activation in vitro and inhibition of mycobacterial respiration in vivo. J. Bacteriol. 2004, 186, 5427-5431. [CrossRef]

21. Sekiguchi, J.; Miyoshi-Akiyama, T.; Augustynowicz-Kopec, E.; Zwolska, Z.; Kirikae, F.; Toyota, E.; Kobayashi, I.; Morita, K.; Kudo, K.; Kato, S.; et al. Detection of multidrug resistance in Mycobacterium tuberculosis. J. Clin. Microbiol. 2007, 45, 179-192. [CrossRef]

22. Vosátka, R.; Krátký, M.; Švarcová, M.; Janoušek, J.; Stolař́ková, J.; Madacki, J.; Huszár, S.; Mikušová, K.; Korduláková, J.; Trejtnar, F.; et al. New lipophilic isoniazid derivatives and their 1,3,4-oxadiazole analogues: Synthesis, antimycobacterial activity and investigation of their mechanism of action. Eur. J. Med. Chem. 2018, 151, 824-835. [CrossRef] [PubMed]

23. Ellard, G.A.; Gammon, P.T.; Wallace, S.M. The determination of isoniazid and its metabolites acetylisoniazid, monoacetylhydrazine, diacetylhydrazine, isonicotinic acid and isonicotinylglycine in serum and urine. Biochem. J. 1972, 126, 449-458. [CrossRef]

24. Huang, Y.S.; Chern, H.D.; Su, W.J.; Wu, J.C.; Lai, S.L.; Yang, S.Y.; Chang, F.Y.; Lee, S.D. Polymorphism of the $\mathrm{N}$-acetyltransferase 2 gene as a susceptibility risk factor for antituberculosis drug-induced hepatitis. Hepatology 2002, 35, 883-889. [CrossRef] [PubMed]

25. Wang, P.; Pradhan, K.; Zhong, X.B.; Ma, X. Isoniazid metabolism and hepatotoxicity. Acta Pharm. Sin B. 2016, 6, 384-392. [CrossRef] [PubMed]

26. Butcher, N.J.; Boukouvala, S.; Sim, E.; Minchin, R.F. Pharmacogenetics of the arylamine N-acetyltransferases. Pharmacogenomics J. 2002, 2, 30-42. [CrossRef]

27. Parkin, D.P.; Vandenplas, S.; Botha, F.J.; Vandenplas, M.L.; Seifart, H.I.; Van Helden, P.D.; Van Der Walt, B.J.; Donald, P.R.; Van Jaarsveld, P.P. Trimodality of isoniazid elimination: Phenotype and genotype in patients with tuberculosis. Am. J. Respir. Crit. Care Med. 1997, 155, 1717-1722. [CrossRef]

28. Weiner, M.; Burman, W.; Vernon, A.; Benator, D.; Peloquin, C.A.; Khan, A.; Weis, S.; King, B.; Shah, N.; Hodge, T.; et al. Low isoniazid concentrations and outcome of tuberculosis treatment with once-weekly isoniazid and rifapentine. Am. J. Respir. Crit. Care Med. 2003, 167, 1341-1347. [CrossRef] 
29. Ohno, M.; Yamaguchi, I.; Yamamoto, I.; Fukuda, T.; Yokota, S.; Maekura, R.; Ito, M.; Yamamoto, Y.; Ogura, T.; Maeda, K.; et al. Slow N-acetyltransferase 2 genotype affects the incidence of isoniazid and rifampicin-induced hepatotoxicity. Int. J. Tuberc. Lung Dis. 2000, 4, 256-261.

30. Saukkonen, J.J.; Cohn, D.L.; Jasmer, R.M.; Schenker, S.; Jereb, J.A.; Nolan, C.M.; Peloquin, C.A.; Gordin, F.M.; Nunes, D.; Strader, D.B.; et al. An official ATS statement: Hepatotoxicity of antituberculosis therapy. Am. J. Respir. Crit. Care Med. 2006, 174, 935-952. [CrossRef]

31. Hearn, M.J.; Cynamon, M.H. Design and synthesis of antituberculars: Preparation and evaluation against Mycobacterium tuberculosis of an isoniazid Schiff base. J. Antimicrob. Chemoth. 2004, 53, 185-191. [CrossRef]

32. Zhang, J.L.; Wang, X.M.; Yang, J.F.; Guo, L.N.; Wang, X.L.; Song, B.; Dong, W.; Wang, W.B. Novel diosgenin derivatives containing 1,3,4-oxadiazole/thiadiazole moieties as potential antitumor agents: Design, synthesis and cytotoxic evaluation. Eur. J. Med. Chem. 2020, 186, 111897. [CrossRef] [PubMed]

33. Carvalho, S.A.; Da Silva, E.F.; De Souza, M.V.; Lourenco, M.C.; Vicente, F.R. Synthesis and antimycobacterial evaluation of new trans-cinnamic acid hydrazide derivatives. Bioorg. Med. Chem. Lett. 2008, 18, 538-541. [CrossRef] [PubMed]

34. Hearn, M.J.; Cynamon, M.H. In vitro and in vivo activities of acylated derivatives of isoniazid against mycobacterium tuberculosis. Drug Des. Discov. 2003, 18, 103-108. [CrossRef] [PubMed]

35. Judge, V.; Narasimhan, B.; Ahuja, M. Isoniazid: The magic molecule. Med. Chem. Res. 2012, 21, $3940-3957$. [CrossRef]

36. Junior, I.N.; Lourenço, M.C.S.; De Miranda, G.B.P.; Vasconcelos, T.R.A.; Pais, K.C.; Junior, J.P.A.; Wardell, S.M.S.V.; Wardell, J.L.; De Souza, M.V.N. Synthesis and in vitro anti-tubercular activity of a series of N'-(disubstitutedbenzoyl)isoniazid derivatives. Lett. Drug Des. Discov. 2006, 3, 424-428. [CrossRef]

37. Lingala, S.; Nerella, R.; Cherukupally, R.; Das, A.K. Synthesis and comparative anti-tubercular activity of indolizine derivatives of isoniazid / pyrazinamide / ethionamide. Int. J. Pharm. Sci. Rev. Res. 2011, 6, 128-131.

38. Mohamad, S.; Ibrahim, P.; Sadikun, A. Susceptibility of Mycobacterium tuberculosis to isoniazid and its derivative, 1-isonicotinyl-2-nonanoyl hydrazine: Investigation at cellular level. Tuberculosis 2004, 84, 56-62. [CrossRef]

39. Reis, W.J.; Bozzi, Í.A.; Ribeiro, M.F.; Halicki, P.C.; Ferreira, L.A.; da Silva, P.E.A.; Ramos, D.F.; de Simone, C.A.; da Silva Júnior, E.N. Design of hybrid molecules as antimycobacterial compounds: Synthesis of isoniazid-naphthoquinone derivatives and their activity against susceptible and resistant strains of Mycobacterium tuberculosis. Bioorg. Med. Chem. 2019, 27, 4143-4150. [CrossRef]

40. Judge, V.; Narasimhan, B.; Ahuja, M.; Sriram, D.; Yogeeswari, P.; De Clercq, E.; Pannecouque, C.; Balzarini, J. Isonicotinic acid hydrazide derivatives: Synthesis, antimicrobial activity, and QSAR studies. Med. Chem. Res. 2012, 21, 1451-1470. [CrossRef]

41. Ventura, C.; Martins, F. Application of quantitative structure-activity relationships to the modeling of antitubercular compounds. 1. The hydrazide family. J. Med. Chem. 2008, 51, 612-624. [CrossRef]

42. Telehoiu Bordei, A.T.; Nuță, D.C.; Căproiu, M.T.; Dumitrascu, F.; Zarafu, I.; Ioniță, P.; Bădiceanu, C.D.; Avram, S.; Chifiriuc, M.C.; Bleotu, C.; et al. Design, Synthesis and In Vitro Characterization of Novel Antimicrobial Agents Based on 6-Chloro-9H-carbazol Derivatives and 1,3,4-Oxadiazole Scaffolds. Molecules 2020, 25, 266. [CrossRef] [PubMed]

43. Limban, C.; Nuta, D.C.; Missir, A.V.; Roman, R.; Caproiu, M.T.; Dumitrascu, F.; Pintilie, L.; Stefaniu, A.; Chifiriuc, M.C.; Popa, M.; et al. Synthesis and Characterization of New Fluoro/Trifluoromethyl-Substituted Acylthiourea Derivatives with Promising Activity against Planktonic and Biofilm-Embedded Microbial Cells. Processes 2020, 8, 503. [CrossRef]

44. Radulescu, C.; Stihi, C. Biological activity of new heterocyclic systems containing thiazolic ring. Rev. Chimie 2009, 60, 1164-1168.

45. Radulescu, C.; Ionita, I.; Hossu, A.M. Synthesis of linear bis-thiazolo [2,3-d][8, 9-d] trans-quinacridone. Dyes Pigm. 2005, 65, 175-177. [CrossRef]

46. Radulescu, C.; Hossu, A.M. New alkylated diquinoxaline-piperazine dicarboxylic acids obtained by synthesis. Rev. Chimie 2005, 56, 742-745.

47. Wang, X.; Inoyama, D.; Russo, R.; Li, S.-G.; Jadhav, R.; Stratton, T.P.; Mittal, N.; Bilotta, J.A.; Singleton, E.; Kim, T.; et al. Antitubercular Triazines: Optimization and Intrabacterial Metabolism. Cell Chem. Biol. 2020, $27,172-185$. 
48. Caneschi, W.; Enes, K.B.; de Mendonça, C.C.; de Souza Fernandes, F.; Miguel, F.B.; da Silva Martins, J.; Le Hyaric, M.; Pinho, R.R.; Duarte, L.M.; de Oliveira, M.A.L.; et al. Synthesis and anticancer evaluation of new lipophilic 1,2,4 and 1,3,4-oxadiazoles. Eur. J. Med. Chem. 2019, 165, 18-30. [CrossRef]

49. Limban, C.; Missir, A.V.; Chirita, I.C.; Badiceanu, C.D.; Draghici, C.; Balotescu, M.C.; Stamatoiu, O. New thioureides of 2-(4-methyl-phenoxymethyl)-benzoic and 2-(4-methoxy-phenoxymethyl)-benzoic acids with biological activity. Rev. Roum. Chim. 2008, 53, 595-602.

50. Navarrete-Vazquez, G.; Molina-Salinas, G.M.; Duarte-Fajardo, Z.V.; Vargas-Villarreal, J.; Estrada-Soto, S.; Gonzalez-Salazar, F.; Hernandez-Nunez, E.; Said-Fernandez, S. Synthesis and antimycobacterial activity of 4-(5-substituted-1,3,4-oxadiazol-2-yl)pyridines. Bioorg. Med. Chem. 2007, 15, 5502-5508. [CrossRef]

51. Matei, L.; Bleotu, C.; Baciu, I.; Diaconu, C.C.; Hanganu, A.; Banu, O.; Ionita, P.; Paun, A.; Tatibouët, A.; Zarafu, I. Synthesis and biological activities of some new isonicotinic acid 2-(2-hydroxy-8-substituted-tricyclo[7.3.1.0.7 ${ }^{2.7}$ tridec-13-ylidene)-hydrazides. Bioorg. Med. Chem. 2015, 23, 401-410. [CrossRef]

52. Desta, Z.; Soukhova, N.V.; Flockhart, D.A. Inhibition of cytochrome P450 (CYP450) isoforms by isoniazid: Potent inhibition of CYP2C19 and CYP3A. Antimicrob. Agents Chemother. 2001, 45, 382-392. [CrossRef] [PubMed]

53. Wen, X.; Wang, J.S.; Neuvonen, P.J.; Backman, J.T. Isoniazid is a mechanism-based inhibitor of cytochrome P450 1A2, 2A6, 2C19 and 3A4 isoforms in human liver microsomes. Eur. J. Clin. Pharmacol. 2002, 57, 799-804. [CrossRef] [PubMed]

54. El-Sayed, W.M.; Aboul-Fadl, T.; Franklin, M.R. Effects of isatin-isoniazid derivatives on drug metabolizing and chemoprotective enzymes in mice. Drug Dev. Res. 2010, 71, 313-322. [CrossRef]

55. Zanger, U.M.; Schwab, M. Cytochrome P450 enzymes in drug metabolism: Regulation of gene expression, enzyme activities, and impact of genetic variation. Pharmacol. Therapeutics. 2013, 138, 103-141. [CrossRef] [PubMed]

56. Kumar, H.; Malhotra, D.; Sharma, R.; Sausville, E.; Malhotra, M. Synthesis, characterization and evaluation of Isoniazid analogues as potent anticancer agents. Pharmacologyonline 2011, 3, 337-343.

57. Rodrigues, F.A.; Oliveira, A.C.; Cavalcanti, B.C.; Pessoa, C.; Pinheiro, A.C.; De Souza, M.V. Biological evaluation of isoniazid derivatives as an anticancer class. Sci. Pharm. 2014, 82, 21-28. [CrossRef]

58. Nakajima, T.; Wang, R.S.; Elovaara, E.; Gonzalez, F.J.; Gelboin, H.V.; Raunio, H.; Pelkonen, O.; Vainio, H.; Aoyama, T. Toluene metabolism by cDNA-expressed human hepatic cytochrome P450. Biochem. Pharmacol. 1997, 53, 271-277. [CrossRef]

59. Coleman, M.D. Human Drug Metabolism; John Wiley \& Sons Ltd.: Hoboken, NJ, USA, 2010; Chapter 3; pp. 23-64.

60. Staack, R.F.; Theobald, D.S.; Paul, L.D.; Springer, D.; Kraemer, T.; Maurer, H.H. In vivo metabolism of the new designer drug 1-(4-methoxyphenyl) piperazine (MeOPP) in rat and identification of the human cytochrome P450 enzymes responsible for the major metabolic step. Xenobiotica 2004, 34, 179-192. [CrossRef]

61. Porter, A.G. Flipping the safety catch of procaspase-3. Nat. Chem. Biol. 2006, 2, 509-510. [CrossRef]

62. Matthess, Y.; Raab, M.; Sanhaji, M.; Lavrik, I.N.; Strebhardt, K. Cdk1/cyclin B1 controls Fas-mediated apoptosis by regulating caspase-8 activity. Mol. Cell Biol. 2010, 30, 5726-5740. [CrossRef]

63. Allan, L.A.; Clarke, P.R. Phosphorylation of caspase-9 by CDK1/cyclin B1 protects mitotic cells against apoptosis. Mol. Cell. 2007, 26, 301-310. [CrossRef] [PubMed]

64. Nantajit, D.; Fan, M.; Duru, N.; Wen, Y.; Reed, J.C.; Li, J.J. Cyclin B1/Cdk1 Phosphorylation of Mitochondrial p53 Induces Anti-Apoptotic Response. PLoS ONE 2010, 5, e12341. [CrossRef] [PubMed]

65. Gao, J.; Richardson, D.R. The potential of iron chelators of the pyridoxal isonicotinoyl hydrazone class as effective antiproliferative agents, IV: The mechanisms involved in inhibiting cell-cycle progression. Blood 2001, 98, 842-850. [CrossRef] [PubMed]

66. Nurtjahja-Tjendraputra, E.; Fu, D.; Phang, J.M.; Richardson, D.R. Iron chelation regulates cyclin D1 expression via the proteasome: A link to iron deficiency-mediated growth suppression. Blood 2007, 109, 4045-4054. [CrossRef]

67. Radulescu, C.; Hossu, A.M.; Ionita, I. Disperse dyes' derivatives from compact condensed system 2-aminothiazolo [5, 4-c] pyridine: Synthesis and characterization. Dyes Pigm. 2006, 71, 123-129. [CrossRef]

68. Radulescu, C.; Tarabasanu-Mihaila, C.; Hossu, A.M.; Ionita, I. The comparative study on the synthesis methods of a heterocyclic system 2-aminothiazolo [4, 5-b] pyridine. Rev. Chimie. 2005, 56, 659-662. 
69. Radulescu, C. Synthesis and characterization of diquinoxaline [2, 3-b][2, 3-e] piperazine-6, 6' -dicarboxylic acid and diquinoxaline [2, 3-b][2, 3-e] piperazine-6, 7'-dicarboxylic acid. Rev. Chimie 2005, 56, 151-154.

70. Radulescu, C.; Tarabasanu-Mihaila, C.; Hossu, A.M.; Ionita, I. Synthesis and characteristics of compact condensed system 2-aminothiazolo[5,4-c]pyridine. Rev. Chimie 2004, 55, 889-893.

71. Franzblau, S.G.; Witzig, R.S.; Mclaughlin, J.C.; Torres, P.; Madico, G.; Hernandez, A.; Degnan, M.T.; Cook, M.B.; Quenzer, V.K.; Ferguson, R.M.; et al. Rapid, low-technology MIC determination with clinical Mycobacterium tuberculosis isolates by using the microplate Alamar Blue assay. J. Clin. Microbiol. 1998, 36, 362-366. [CrossRef]

Sample Availability: Samples of the compounds are available from the authors.

(C) 2020 by the authors. Licensee MDPI, Basel, Switzerland. This article is an open access article distributed under the terms and conditions of the Creative Commons Attribution (CC BY) license (http://creativecommons.org/licenses/by/4.0/). 